\title{
Seasonal study of stable carbon and nitrogen isotopic composition in fine aerosols at a Central European rural background station
}

\author{
Petr Vodička ${ }^{1,2}$, Kimitaka Kawamura $^{1}$, Jaroslav Schwarz $^{2}$, Bhagawati Kunwar $^{1}$, and Vladimír Ždímal ${ }^{2}$ \\ ${ }^{1}$ Chubu Institute for Advanced Studies, Chubu University, 1200 Matsumoto-cho, Kasugai 487-8501, Japan \\ ${ }^{2}$ Institute of Chemical Process Fundamentals, Czech Academy of Sciences, Rozvojová 2/135, \\ 165 02, Prague 6, Czech Republic
}

Correspondence: Petr Vodička (vodicka@icpf.cas.cz) and Kimitaka Kawamura (kkawamura@isc.chubu.ac.jp)

Received: 19 June 2018 - Discussion started: 12 September 2018

Revised: 13 January 2019 - Accepted: 4 March 2019 - Published: 19 March 2019

\begin{abstract}
A study of the stable carbon isotope ratios $\left(\delta^{13} \mathrm{C}\right)$ of total carbon (TC) and the nitrogen isotope ratios $\left(\delta^{15} \mathrm{~N}\right)$ of total nitrogen (TN) was carried out for fine aerosol particles $\left(\mathrm{PM}_{1}\right)$ and was undertaken every 2 days with a $24 \mathrm{~h}$ sampling period at a rural background site in Košetice (Central Europe) from 27 September 2013 to 9 August $2014(n=146)$. We found a seasonal pattern for both $\delta^{13} \mathrm{C}$ and $\delta^{15} \mathrm{~N}$. The seasonal variation in $\delta^{15} \mathrm{~N}$ was characterized by lower values (average of $13.1 \pm 4.5 \%$ ) in winter and higher values $(25.0 \pm 1.6 \%$ ) in summer. Autumn and spring were transition periods when the isotopic composition gradually changed due to the changing sources and ambient temperature. The seasonal variation in $\delta^{13} \mathrm{C}$ was less pronounced but more depleted in ${ }^{13} \mathrm{C}$ in summer $(-27.8 \pm 0.4 \%$ ) as compared to winter $(-26.7 \pm 0.5 \%$ ) .
\end{abstract}

A comparative analysis with water-soluble ions, organic carbon, elemental carbon, trace gases and meteorological parameters (mainly ambient temperature) has shown major associations with the isotopic compositions, which has provided greater knowledge and understanding of the corresponding processes. A comparison of $\delta^{15} \mathrm{~N}$ with $\mathrm{NO}_{3}^{-}, \mathrm{NH}_{4}^{+}$ and organic nitrogen $(\mathrm{OrgN})$ revealed that although a higher content of $\mathrm{NO}_{3}^{-}$was associated with a decrease in the $\delta^{15} \mathrm{~N}$ of $\mathrm{TN}, \mathrm{NH}_{4}^{+}$and OrgN caused increases. The highest concentrations of nitrate, mainly represented by $\mathrm{NH}_{4} \mathrm{NO}_{3}$ related to the emissions from biomass burning leading to an average $\delta^{15} \mathrm{~N}$ of TN (13.3\%o) in winter. During spring, the percentage of $\mathrm{NO}_{3}^{-}$in $\mathrm{PM}_{1}$ decreased. An enrichment of ${ }^{15} \mathrm{~N}$ was probably driven by the equilibrium exchange between the gas and aerosol phases $\left(\mathrm{NH}_{3}(\mathrm{~g}) \leftrightarrow \mathrm{NH}_{4}^{+}(\mathrm{p})\right)$, which is supported by the increased ambient temperature. This equilib- rium was suppressed in early summer when the molar ratios of $\mathrm{NH}_{4}^{+} / \mathrm{SO}_{4}^{2-}$ reached 2 , and the nitrate partitioning in aerosol was negligible due to the increased ambient temperature. Summertime $\delta^{15} \mathrm{~N}$ values were among the highest, suggesting the aging of ammonium sulfate and OrgN aerosols. Such aged aerosols can be coated by organics in which ${ }^{13} \mathrm{C}$ enrichment takes place by the photooxidation process. This result was supported by a positive correlation of $\delta^{13} \mathrm{C}$ with ambient temperature and ozone, as observed in the summer season.

During winter, we observed an event with the lowest $\delta^{15} \mathrm{~N}$ and highest $\delta^{13} \mathrm{C}$ values. The winter event occurred in prevailing southeast air masses. Although the higher $\delta^{13} \mathrm{C}$ values probably originated from biomass-burning particles, the lowest $\delta^{15} \mathrm{~N}$ values were probably associated with agriculture emissions of $\mathrm{NH}_{3}$ under low-temperature conditions $\left(<0{ }^{\circ} \mathrm{C}\right)$.

\section{Introduction}

Aerosols have a strong impact on key processes in the atmosphere associated with climate change, air quality, rain patterns and visibility (Fuzzi et al., 2015; Hyslop, 2009). Because these processes are still insufficiently understood, they are studied intensively. One approach for exploring chemical processes taking place in atmospheric aerosols is the application of stable carbon $\left(\delta^{13} \mathrm{C}\right)$ and nitrogen $\left(\delta^{15} \mathrm{~N}\right)$ isotope ratios. These isotopes can provide unique insight into source emissions, along with physical and chemical processes in the atmosphere (Gensch et al., 2014; Kawamura et al., 2004) 
as well as historical atmospheric compositions (Dean et al., 2014). However, studies based on single-isotope analysis have their limitations (Meier-Augenstein and Kemp, 2012). These include an uncertainty when multiple sources or different processes are present, whose measured delta values may overlap (typically in the narrower $\delta^{13} \mathrm{C}$ range). Another factor is isotope fractionation processes which may compromise the accuracy of source identification (Xue et al., 2009). Using isotope analysis on multiple phases (gas and particulate matter) or multiple-isotope analysis can overcome these problems and may be useful to constrain the potential sources and processes.

Generally, isotopic composition is affected by both primary emissions (e.g., Heaton, 1990; Widory, 2006) and secondary processes (e.g., Fisseha et al., 2009b; Walters et al., 2015a). Isotopes are furthermore altered mainly by kinetic and/or equilibrium fractionation processes. Kinetic isotope effects (KIEs) occur mainly during unidirectional (irreversible) reactions but also during diffusion or reversible reactions that are not yet at equilibrium (Gensch et al., 2014). Owing to KIE, reaction products (both gases and particles) are depleted in the heavy isotope relative to the reactants, and this effect is generally observed in organic compounds (Irei et al., 2006). If the partitioning between phases is caused by nonequilibrium processes (e.g., absorption), the isotopic fractionation is small and lower than that caused by chemical reactions (Rahn and Eiler, 2001). Equilibrium isotope effects occur in reversible chemical reactions or phase changes if the system is in equilibrium. Under such conditions the heavier isotope is bound into the compounds where the total energy of the system is minimized and the most stable. Equilibrium effects are typical for inorganic species and usually temperature dependent.

Regarding the isotopic distribution in individual phases, ${ }^{15} \mathrm{~N}$ is generally depleted in gas-phase precursors (ammonia, nitrogen oxides) but is more enriched in ions $\left(\mathrm{NH}_{4}^{+}, \mathrm{NO}_{3}^{-}\right)$ in rainfall and the most enriched in particulate matter and dry deposition (Heaton et al., 1997; Ti et al., 2018). Total nitrogen usually consists of the three main components, $\mathrm{NO}_{3}^{-}$, $\mathrm{NH}_{4}^{+}$and/or organic nitrogen ( $\left.\mathrm{OrgN}\right)$, and thus the final $\delta^{15} \mathrm{~N}$ value in total nitrogen (TN) can be formulated by the following equation:

$$
\begin{aligned}
\delta^{15} \mathrm{~N}_{\mathrm{TN}} & =\delta^{15} \mathrm{~N}_{\mathrm{NO}_{3}} \times f_{\mathrm{NO}_{3}}+\delta^{15} \mathrm{~N}_{\mathrm{NH}_{4}} \times f_{\mathrm{NH}_{4}} \\
& +\delta^{15} \mathrm{~N}_{\mathrm{OrgN}} \times f_{\mathrm{OrgN}},
\end{aligned}
$$

where $f_{\mathrm{NO}_{3}}+f_{\mathrm{NH}_{4}}+f_{\mathrm{OrgN}}=1$ and $f$ represents the fractions of nitrogen from $\mathrm{NO}_{3}^{-}, \mathrm{NH}_{4}^{+}$and $\mathrm{OrgN}$ in $\mathrm{TN}$, respectively.

Total carbon in aerosol is usually divided into elemental carbon (EC) and organic carbon (OC), where OC forms the major part of total carbon (TC) (e.g., Mbengue et al., 2018). Although EC is more or less inert to chemical changes, slightly different $\delta^{13} \mathrm{C}$ in EC originating from primary emissions is described (Kawashima and Haneishi, 2012). OC represents a wide variety of organic compounds which can orig- inate from different sources with different ${ }^{13} \mathrm{C}$ content resulting in different $\delta^{13} \mathrm{C}$ values in the bulk of emissions. Changes in the isotopic ratio of $\delta^{13} \mathrm{C}$ in OC (and thus also TC) can subsequently affect chemical reactions where isotope fractionations via the KIE usually dominate the partitioning between gas and aerosol (liquid or solid) phases (e.g., Zhang et al., 2016).

Many studies have been conducted on $\delta^{13} \mathrm{C}$ and $\delta^{15} \mathrm{~N}$ in particulate matter (PM) in Asia (e.g., Kundu et al., 2010; Pavuluri et al., 2015b; Pavuluri and Kawamura, 2017) and the Americas (e.g., Martinelli et al., 2002; Savard et al., 2017). Recently, the multiple-isotope approach was applied in several studies by using $\delta^{13} \mathrm{C}$ and $\delta^{15} \mathrm{~N}$ measurements. Specifically, the $\delta^{13} \mathrm{C}$ and $\delta^{15} \mathrm{~N}$ composition of aerosol (along with other supporting data) was used to identify the sources and processes at marine sites in Asia (Bikkina et al., 2016; Kunwar et al., 2016; Miyazaki et al., 2011; Xiao et al., 2018). The same isotopes were used to determine the contribution of biomass burning to organic aerosols in India (Boreddy et al., 2018) and in Tanzania (Mkoma et al., 2014) or to unravel the sources of aerosol contamination at Cuban rural and urban coastal sites (Morera-Gómez et al., 2018). These studies show the potential advantages of $\delta^{13} \mathrm{C}$ and $\delta^{15} \mathrm{~N}$ isotope ratios for characterizing aerosol types and revealing the underlying chemical processes that take place in them.

Only a few studies on $\delta^{13} \mathrm{C}$ and $\delta^{15} \mathrm{~N}$ isotope ratios have been performed in Europe, which are moreover often based on single-isotope analysis. Regarding the isotopes of nitrogen, Widory (2007) published a broad study on $\delta^{15} \mathrm{~N}$ in TN in $\mathrm{PM}_{10}$ samples from Paris, focusing on seasonality (winter vs. summer) with some specific sources. Freyer (1991) reported the seasonal variation in the $\delta^{15} \mathrm{~N}$ of nitrate in aerosols and rainwater, as well as gaseous $\mathrm{HNO}_{3}$ in a moderately polluted urban area in Jülich (Germany). Yeatman et al. (2001a, b) conducted analyses of $\delta^{15} \mathrm{~N}_{\text {in }} \mathrm{NO}_{3}^{-}$and $\mathrm{NH}_{4}^{+}$at two coastal sites in Weybourne, England, and Mace Head, Ireland, focusing on the effects of the possible sources and aerosol size segregation on their formation processes and isotopic enrichment. More recently, Ciężka et al. (2016) reported 1-year observations of $\delta^{15} \mathrm{~N}$ in $\mathrm{NH}_{4}^{+}$and ions in precipitation at an urban site in Wrocław, Poland, whereas Beyn et al. (2015) reported seasonal changes in $\delta^{15} \mathrm{~N}^{\text {in }} \mathrm{NO}_{3}^{-}$in wet and dry deposition at a coastal and an urban site in Germany to evaluate nitrogen pollution levels.

Studies on $\delta^{13} \mathrm{C}$ at European sites have been focused more on urban aerosols. Fisseha et al. (2009a) used stable carbon isotopes of the different carbonaceous aerosol fractions (TC, black carbon and water-soluble and insoluble OC) to determine the sources of urban aerosols in Zurich, Switzerland, during winter and summer. Similarly, Widory et al. (2004) used $\delta^{13} \mathrm{C}$ of TC, along with an analysis of lead isotopes, to study the origin of aerosol particles in Paris (France). Górka et al. (2014) used $\delta^{13} \mathrm{C}$ in TC in conjunction with polyaromatic hydrocarbon $(\mathrm{PAH})$ analyses for 
the determination of the sources of $\mathrm{PM}_{10}$ organic matter in Wrocław, Poland, during the vegetative and heating seasons. Masalaite et al. (2015) used an analysis of $\delta^{13} \mathrm{C}$ in TC on size-segregated urban aerosols to elucidate carbonaceous PM sources in Vilnius, Lithuania. Fewer studies have been conducted on $\delta^{13} \mathrm{C}$ in aerosols in rural and remote areas of $\mathrm{Eu}-$ rope. In the 1990s, Pichlmayer et al. (1998) conducted a

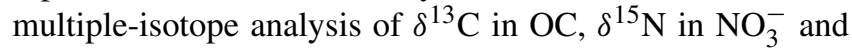
$\delta^{34} \mathrm{~S}$ in $\mathrm{SO}_{4}^{2-}$ in snow and air samples for the characterization of pollutants at high-alpine sites in Central Europe. Recently, Martinsson et al. (2017) published seasonal observations of $\delta^{13} \mathrm{C}$ in $\mathrm{TC}$, along with the ${ }^{14} \mathrm{C} /{ }^{12} \mathrm{C}$ isotope ratio of $\mathrm{PM}_{10}$ at a rural background station in Vavihill in southern Sweden based on 25 weekly samples.

To broaden the multiple-isotope approach over the European continent, we present seasonal variations in $\delta^{13} \mathrm{C}$ of TC and $\delta^{15} \mathrm{~N}$ of $\mathrm{TN}$ in the $\mathrm{PM}_{1}$ fraction of atmospheric aerosols at a rural background site in Central Europe. To the best of our knowledge, this is the first seasonal study of these isotopes in this region, and it is one of the most comprehensive isotope studies of fine aerosol fraction.

\section{Materials and methods}

\subsection{Measurement site}

The Košetice observatory is a key station of the Czech Hydrometeorological Institute (CHMI), focusing on air quality and environmental monitoring (Váňa and Dvorská, 2014). The site is located in the Czech Highlands $\left(49^{\circ} 34^{\prime} 24.13^{\prime \prime} \mathrm{N}\right.$, $15^{\circ} 4^{\prime} 49.67^{\prime \prime} \mathrm{E}, 534 \mathrm{~m}$ a.s.1.) and is surrounded by an agricultural landscape and forests, which are out of range of major sources of pollution and have very low traffic density. The observatory is officially classified as a Central European rural background site, which is part of the European Monitoring and Evaluation Programme (EMEP), Aerosol, Clouds and Trace Gases Research Infrastructure (ACTRIS) and Global Atmosphere Watch (GAW) networks. A characterization of the station in terms of the chemical composition of fine aerosols during different seasons and air masses is presented by Schwarz et al. (2016), and longtime trends are presented by Mbengue et al. (2018) and Pokorná et al. (2018). As part of a monitoring network operated by the CHMI, the site is equipped with an automated monitoring system that provides meteorological data (wind speed and direction, relative humidity, temperature, pressure, and solar radiation) and the concentrations of gaseous pollutants $\left(\mathrm{SO}_{2}, \mathrm{CO}, \mathrm{NO}, \mathrm{NO}_{2}\right.$, $\mathrm{NO}_{x}$ and $\mathrm{O}_{3}$ ).

\subsection{Sampling and weighing}

Aerosol samples were collected every 2 days for $24 \mathrm{~h}$ from 27 September 2013 to 9 August 2014, using a Leckel sequential sampler SEQ47/50 equipped with a $\mathrm{PM}_{1}$ sampling inlet.
Some temporal gaps were caused by sampler maintenance or power outages resulting in 146 samples during the almost year-long study. The sampler was loaded with prebaked $(3 \mathrm{~h}$, $800^{\circ} \mathrm{C}$ ) quartz fiber filters (Tissuequartz, Pall, $47 \mathrm{~mm}$ ) and operated at a flow rate of $2.3 \mathrm{~m}^{3} \mathrm{~h}^{-1}$. In addition, field blanks $(n=7)$ were also taken for an analysis of the contribution of adsorbed organic vapors (positive artifact).

The $\mathrm{PM}_{1}$ was measured gravimetrically (each filter before and after the sampling) with a microbalance that had $\pm 1 \mu \mathrm{g}$ sensitivity (Sartorius M5P, Sartorius AG, Göttingen, Germany) in a controlled environment $\left(20 \pm 1{ }^{\circ} \mathrm{C}\right.$ and $50 \pm 3 \%$ relative humidity after filter equilibration for $24 \mathrm{~h}$ ).

\subsection{Determination of $\mathrm{TC}$ and $\mathrm{TN}$ concentrations and their stable isotopes}

For the measurements of TC and TN and their stable isotope ratios, small filter discs (area $0.5,1.13$ or $2.01 \mathrm{~cm}^{2}$ ) were placed in a pre-cleaned tin cup, shaped into a small marble using a pair of tweezers and introduced into the elemental analyzer (EA; Flash 2000) using an autosampler. Inside the EA, samples were first oxidized in a quartz column heated at $1000^{\circ} \mathrm{C}$, in which the tin marble burns and oxidizes all the carbon and nitrogen species to $\mathrm{CO}_{2}$ and nitrogen oxides, respectively. In the second quartz column, heated to $750^{\circ} \mathrm{C}$, nitrogen oxides were reduced to $\mathrm{N}_{2}$. Evolved $\mathrm{CO}_{2}$ and $\mathrm{N}_{2}$ were subsequently separated on a gas chromatographic column, which was installed in EA and measured with a thermal conductivity detector for TC and TN. $\mathrm{CO}_{2}$ and $\mathrm{N}_{2}$ were then transferred into an isotope ratio mass spectrometer (IRMS; Delta V, Thermo Fisher Scientific) through a ConFlo IV interface to monitor the ${ }^{15} \mathrm{~N} /{ }^{14} \mathrm{~N}$ and ${ }^{13} \mathrm{C} /{ }^{12} \mathrm{C}$ ratios.

An acetanilide external standard (from Thermo Electron Corp.) was used to determine the calibration curves before every set of measurements for calculating TC, TN and their isotope values. The $\delta^{15} \mathrm{~N}$ and $\delta^{13} \mathrm{C}$ values of the acetanilide standard were $11.89 \%$ (relative to the atmospheric nitrogen) and $-27.26 \%$ (relative to the Vienna Pee Dee Belemnite standard), respectively. Subsequently, the $\delta^{15} \mathrm{~N}$ of TN and $\delta^{13} \mathrm{C}$ of TC were calculated using the following equations and the final $\delta$ values are expressed in relation to the international standards:

$$
\begin{aligned}
\delta^{15} \mathrm{~N}(\% o) & =\left[\left({ }^{15} \mathrm{~N} /{ }^{14} \mathrm{~N}\right)_{\text {sample }} /\left({ }^{15} \mathrm{~N} /{ }^{14} \mathrm{~N}\right)_{\text {standard }}-1\right] \\
& \times 1000 \\
\delta^{13} \mathrm{C}(\% o) & =\left[\left({ }^{13} \mathrm{C} /{ }^{12} \mathrm{C}\right)_{\text {sample }} /\left({ }^{13} \mathrm{C} /{ }^{12} \mathrm{C}\right)_{\text {standard }}-1\right] \\
& \times 1000 .
\end{aligned}
$$

\subsection{Ion chromatography}

The load on the quartz filters was further analyzed by using a Dionex ICS-5000 (Thermo Scientific, USA) ion chromatograph (IC). The samples were extracted using ultrapure 
water with conductivity below $0.08 \mu \mathrm{S} \mathrm{m}^{-1}$ (Ultrapur, Watrex Ltd., Czech Rep.) for $0.5 \mathrm{~h}$ using an ultrasonic bath and $1 \mathrm{~h}$ using a shaker. The solution was filtered through a Millipore syringe filter with $0.22 \mu \mathrm{m}$ porosity. The filtered extracts were then analyzed for both anions $\left(\mathrm{SO}_{4}^{2-}, \mathrm{NO}_{3}^{-}, \mathrm{Cl}^{-}\right.$, $\mathrm{NO}_{2}^{-}$and oxalate) and cations $\left(\mathrm{Na}^{+}, \mathrm{NH}_{4}^{+}, \mathrm{K}^{+}, \mathrm{Ca}^{2+}\right.$ and $\mathrm{Mg}^{2+}$ ) in parallel. The anions were analyzed using an anion self-regenerating suppressor (ASRS 300) and an IonPac AS11-HC $(2 \times 250 \mathrm{~mm})$ analytical column and measured with a Dionex conductivity detector. For cations, a cation self-regenerating suppressor (CSRS ULTRA II) and an IonPac CS18 $(2 \mathrm{~m} \times 250 \mathrm{~mm})$ analytical column were used in conjunction with a Dionex conductivity detector. The separation of anions was conducted using $25 \mathrm{mM} \mathrm{KOH}$ as an eluent at a flow rate of $0.38 \mathrm{~mL} \mathrm{~min}^{-1}$, and the separation of cations was conducted using $25 \mathrm{mM}$ methanesulfonic acid at $0.25 \mathrm{~mL} \mathrm{~min}^{-1}$.

The sum of nitrate and ammonium nitrogen showed a good agreement with the measured TN (Fig. S1 in the Supplement), and based on the results of $\mathrm{TN}, \mathrm{NO}_{3}^{-}$and $\mathrm{NH}_{4}^{+}$organic nitrogen $(\mathrm{OrgN})$ was also calculated using the following equation (Wang et al., 2010):

$\operatorname{OrgN}=\mathrm{TN}-14 \times\left[\mathrm{NO}_{3}^{-} / 62+\mathrm{NH}_{4}^{+} / 18\right]$.

\subsection{EC and OC analysis}

Online measurements of OC and EC were obtained from parallel sampling on quartz filters by a field semi-online OC and EC analyzer (Sunset Laboratory Inc., USA) connected to a $\mathrm{PM}_{1}$ inlet. The instrument was equipped with a carbon parallel-plate denuder (Sunset Lab.) to remove volatile organic compounds to avoid a positive bias in the measured OC. Samples were taken at $4 \mathrm{~h}$ intervals, including the thermal-optical analysis, which lasts approximately $15 \mathrm{~min}$. The analysis was performed using the shortened EUSAAR2 protocol, step (gas), temperature $\left({ }^{\circ} \mathrm{C}\right.$ ), duration (s): He 200/90, He 300/90, He 450/90, He 650/135, He-Ox. 500/60, He-Ox. 550/60, He-Ox. 700/60 and He-Ox. 850/100 (Cavalli et al., 2010). Automatic optical corrections for charring were made during each measurement, and a split point between EC and OC was detected automatically (software: RTCalc526, Sunset Lab.). Instrument blanks were measured once per day at midnight, and they only represent a background instrument response without filter exposure. Control calibrations using a sucrose solution were made before each change of the filter (ca. every second week) to check the stability of instruments. The $24 \mathrm{~h}$ averages with identical measuring times, such as on quartz filters, were calculated from the acquired $4 \mathrm{~h}$ data. The sum of EC and OC provided TC concentrations, which were consistent with the TC values measured by EA (see Fig. S2).

\subsection{Spearman correlation calculations}

Spearman correlation coefficients $(r)$ were calculated using $\mathrm{R}$ statistical software (ver. 3.3.1). The correlations were calculated for the annual dataset $(n=139$, without the winter event samples) and separately for each season (autumn: 25; winter: 38; spring: 43 ; and summer: 33 ) and the winter event (7). Data from the winter event were excluded from the annual and winter datasets for the correlation analysis as their distinctly high concentrations and isotopic values might have affected the results. Correlations with $p$ values $<0.05$ were taken as statistically insignificant.

\section{Results and discussion}

The time series of TN, TC and their isotope ratios $\left(\delta^{15} \mathrm{~N}\right.$ and $\delta^{13} \mathrm{C}$ ) for the whole measurement campaign are depicted in Fig. 1. Some sampling gaps were caused in autumn and at the end of spring due to servicing or outages of the sampler. However, 146 of the samples from 27 September 2013 to 9 August 2014 are sufficient for a seasonal study. In Fig. 1, the winter event is highlighted, which has divergent values, especially for $\delta^{15} \mathrm{~N}$, and is discussed in detail in Sect. 3.4.

Table 1 summarizes the results for the four seasons: autumn (September-November), winter (December-February), spring (March-May) and summer (June-August). The higher TN concentrations were observed in spring (max. $7.59 \mu \mathrm{gN} \mathrm{m}^{-3}$ ), while the higher TC concentrations were obtained during the winter event (max. $13.6 \mu \mathrm{gC} \mathrm{m}^{-3}$ ). Conversely, the lowest TN and TC concentrations were observed in summer (Table 1).

Figure 2 shows the relationships between the TC and TN concentrations and their stable isotopes for 1 year. The correlation between TC and TN is a significant $(r=0.71)$, but the relationship split during high-concentration events due to divergent sources. The highest correlations between TC and TN were obtained during transition periods in autumn $(0.85)$ and spring $(0.80)$. Correlations between TC and TN in winter (0.43) and summer (0.37) were weaker but still statistically significant $(p<0.05)$. As seen in Table 1 , the seasonal averages of TC/TN ratios fluctuate, but their medians have similar values for autumn, winter and spring. The summer TC/TN value is higher (3.45) and characteristic of a significant shift in chemical composition, which is in line with previous studies at the site (Schwarz et al., 2016). However, seasonal differences in the TC/TN ratios were not as large as those in other works (e.g., Agnihotri et al., 2011), and thus this ratio itself did not provide much information about aerosol sources.

The correlation between $\delta^{13} \mathrm{C}$ and $\delta^{15} \mathrm{~N}$ (Fig. 2b) is also significant but negative $(-0.69)$. However, there is a statistically significant correlation for spring only $(-0.54)$, while in other seasons correlations are statistically insignificant. This result highlights a significant shift in the sources of carbona- 
Table 1. Seasonal and entire campaign averages \pm standard deviations (medians in brackets) of different variables.

\begin{tabular}{|c|c|c|c|c|c|}
\hline & Autumn & Winter & Spring & Summer & Year \\
\hline$N$ of samples & 25 & 45 & 43 & 33 & 146 \\
\hline $\mathrm{TC}\left[\mu \mathrm{g} \mathrm{m}^{-3}\right]$ (from EA) & $3.61 \pm 1.61(3.30)$ & $4.76 \pm 2.44(3.88)$ & $3.78 \pm 2.03(3.04)$ & $2.71 \pm 0.76(2.68)$ & $3.81 \pm 2.03(3.35)$ \\
\hline $\mathrm{TN}\left[\mu \mathrm{g} \mathrm{m}^{-3}\right]$ & $1.56 \pm 1.18(1.33)$ & $1.67 \pm 0.96(1.45)$ & $2.00 \pm 1.62(1.47)$ & $0.81 \pm 0.29(0.82)$ & $1.56 \pm 1.22(1.26)$ \\
\hline$\delta^{13} \mathrm{C}[\% o]$ & $-26.8 \pm 0.5(-26.9)$ & $-26.7 \pm 0.5(-26.7)$ & $-27.1 \pm 0.5(-27.0)$ & $-27.8 \pm 0.4(-27.7)$ & $-27.1 \pm 0.6(-27.0)$ \\
\hline$\delta^{15} \mathrm{~N}[\% o]$ & $17.1 \pm 2.4(16.9)$ & $13.1 \pm 4.5(15.2)$ & $17.6 \pm 3.5(17.3)$ & $25.0 \pm 1.6(25.1)$ & $17.8 \pm 5.5(16.9)$ \\
\hline $\mathrm{TC} / \mathrm{PM}_{1}[\%]$ & $28 \pm 6(26)$ & $33 \pm 8(32)$ & $38 \pm 15(35)$ & $31 \pm 6(30)$ & $33 \pm 11(31)$ \\
\hline $\mathrm{TN} / \mathrm{PM}_{1}[\%]$ & $11 \pm 3(11)$ & $11 \pm 3(12)$ & $17 \pm 4(17)$ & $9 \pm 2(9)$ & $12 \pm 4(12)$ \\
\hline $\mathrm{NO}_{3}^{-}-\mathrm{N} / \mathrm{TN}[\%]$ & $21 \pm 6(21)$ & $25 \pm 8(28)$ & $22 \pm 8(21)$ & $5 \pm 3(4)$ & $19 \pm 10(20)$ \\
\hline $\mathrm{NH}_{4}^{+}-\mathrm{N} / \mathrm{TN}[\%]$ & $51 \pm 6(51)$ & $51 \pm 9(49)$ & $58 \pm 7(60)$ & $57 \pm 6(57)$ & $54 \pm 8(54)$ \\
\hline $\operatorname{OrgN} / \mathrm{TN}[\%]$ & $28 \pm 8(26)$ & $25 \pm 8(23)$ & $20 \pm 8(19)$ & $39 \pm 6(38)$ & $27 \pm 10(25)$ \\
\hline $\mathrm{TC} / \mathrm{TN}$ & $2.77 \pm 1.10(2.60)$ & $3.34 \pm 1.66(2.68)$ & $2.33 \pm 0.98(2.34)$ & $3.60 \pm 1.23(3.45)$ & $3.01 \pm 1.38(2.61)$ \\
\hline
\end{tabular}

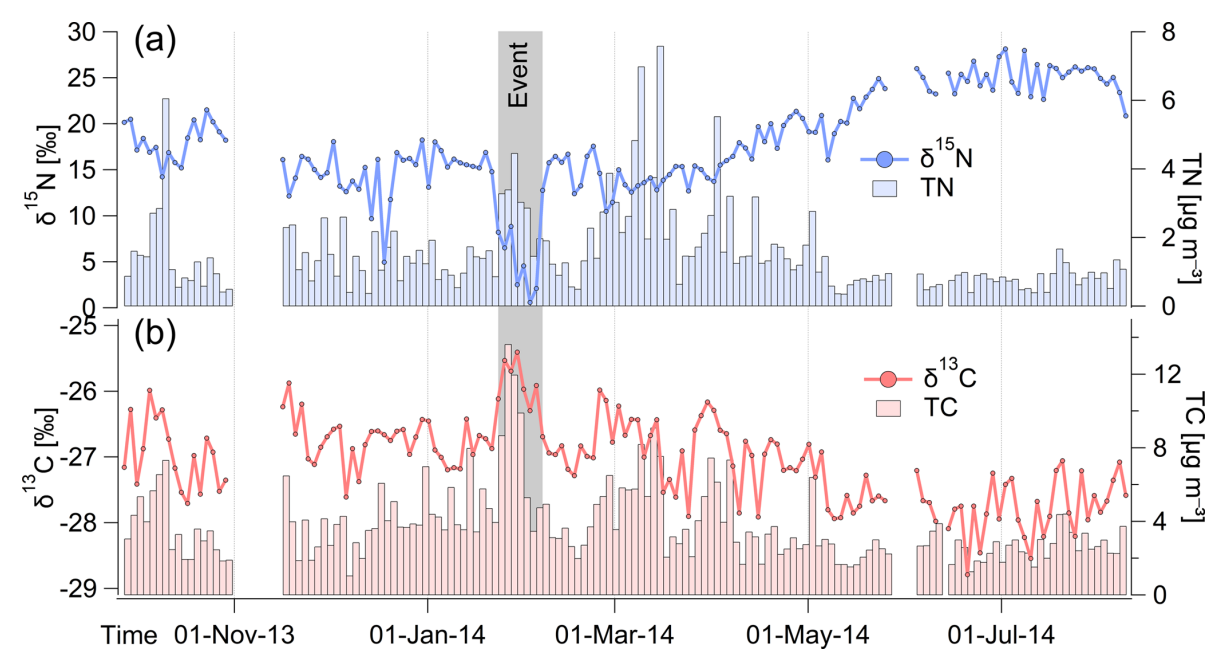

Figure 1. Time series of $\delta^{15} \mathrm{~N}$ with TN (a), and $\delta^{13} \mathrm{C}$ and TC (b) in $\mathrm{PM}_{1}$ aerosols at the Košetice station. The gray color highlights an event with divergent values, especially for $\delta^{15} \mathrm{~N}$.

ceous aerosols and their isotope values in spring, while the sources were rather stable during other seasons. The winter event measurements show the highest $\delta^{13} \mathrm{C}$ and lowest $\delta^{15} \mathrm{~N}$ values, but a linear fit does not show a significant difference compared to rest of the data (Fig. 2b).

\subsection{Total nitrogen and its $\delta^{15} \mathrm{~N}$}

The $\delta^{15} \mathrm{~N}$ values are stable in winter at approximately $15 \%$, with the exception of the winter event, which showed an average of $13 \%$. In summer, the $\delta^{15} \mathrm{~N}$ shows strong enrichment of ${ }^{15} \mathrm{~N}$ in comparison with winter, resulting in an average value of $25 \%$. During the spring period, we observed a slow increase in $\delta^{15} \mathrm{~N}$ from April to June (Fig. 1), indicating a gradual change in nitrogen chemistry in the atmosphere. During autumn, a gradual change is not obvious because of a lack of data in a continuous time series. The range of $\delta^{15} \mathrm{~N}$ was from $0.6 \%$ to $28.2 \%$ year-round. Such a wide range may arise from a limited number of nitrogen-containing species and/or components in aerosols, which are specifically present in the forms of $\mathrm{NO}_{3}^{-}, \mathrm{NH}_{4}^{+}$and/or organic nitrogen (OrgN).
The highest portion of nitrogen is contained in $\mathrm{NH}_{4}^{+}$(54\% of TN year-round), followed by $\operatorname{OrgN}(27 \%)$ and $\mathrm{NO}_{3}^{-}(19 \%)$. Although the $\mathrm{NH}_{4}^{+}$content in $\mathrm{TN}$ is seasonally stable (51\%$58 \%$, Table 1 ), the $\mathrm{NO}_{3}^{-}$content is seasonally dependent: the highest in winter and somewhat lower in spring and autumn. In summer, when the dissociation of $\mathrm{NH}_{4} \mathrm{NO}_{3}$ plays an important role, the $\mathrm{NO}_{3}^{-}$content is very low and its nitrogen is partitioned from the aerosol phase to gas phase (Stelson et al., 1979).

The seasonal trend of $\delta^{15} \mathrm{~N}$ of $\mathrm{TN}$, with the lowest values in winter and highest in summer, has been observed in other studies from urban Paris (Widory, 2007), rural Brazil (Martinelli et al., 2002), and Jeju Island (Kundu et al., 2010) and Baengnyeong Island (Park et al., 2018) in South Korea. However, different seasonal trends of $\delta^{15} \mathrm{~N}$ of TN in Seoul (Park et al., 2018) show that such seasonal variation does not always occur.

Figure 3 shows changes in $\delta^{15} \mathrm{~N}$ values as a function of the main nitrogen components in $\mathrm{TN}$, with different colors for different days. There are two visible trends for types of ni- 
trogen. Although ${ }^{15} \mathrm{~N}$ is more depleted with increasing contents of $\mathrm{NO}_{3}^{-}$in $\mathrm{TN}$, the opposite is true for $\mathrm{NH}_{4}^{+}$and $\mathrm{OrgN}$. The strongest dependence for most bulk data is expressed by a strong negative correlation between $\delta^{15} \mathrm{~N}$ and the fraction of $\mathrm{NO}_{3}^{-}$in TN (Fig. 3). In all cases, the dependence during the winter event is completely opposed to the rest of the bulk data (Fig. 3), suggesting the presence of different processes for $\delta^{15} \mathrm{~N}$ values, which is characterized by a strong positive correlation between $\delta^{15} \mathrm{~N}$ and $\mathrm{NO}_{3}^{-}-\mathrm{N} / \mathrm{TN}(0.98)$. This point will be discussed in Sect. 3.4.

Considering the individual nitrogen components, several studies (Freyer, 1991; Kundu et al., 2010; Yeatman et al., 2001b) showed seasonal trends of $\delta^{15} \mathrm{~N}$ of $\mathrm{NO}_{3}^{-}$, with the lowest $\delta^{15} \mathrm{~N}$ in summer and the highest in winter. Savard et al. (2017, and references therein) summarized four possible reasons for this seasonality of $\delta^{15} \mathrm{~N}$ of $\mathrm{NO}_{3}^{-}$: namely, (i) changes in $\mathrm{NO}_{x}$ emissions, (ii) influence of wind directions in the relative contributions from sources with different isotopic compositions, (iii) the effect of temperature on isotopic fractionation and (iv) chemical transformations of nitrogen oxides over time with a lower intensity of sunlight, which can lead to higher $\delta^{15} \mathrm{~N}$ values of atmospheric nitrate during winter months, as shown by Walters et al. (2015a). In our study, it is most likely that all these factors contributed, to a certain extent, to the nitrogen isotopic composition of $\mathrm{NO}_{3}^{-}$throughout the year.

Conversely, Kundu et al. (2010) reported higher $\delta^{15} \mathrm{~N}$ values of $\mathrm{NH}_{4}^{+}$in summer than in winter and reported higher $\delta^{15} \mathrm{~N}$ values of $\mathrm{NH}_{4}^{+}$than $\mathrm{NO}_{3}^{-}$except for during the winter season. In sum, the contribution of $\mathrm{NH}_{4}^{+}$to $\delta^{15} \mathrm{~N}$ overwhelms that of $\mathrm{NO}_{3}^{-}$. Additionally, $\mathrm{TN}$ is composed of $\mathrm{NH}_{4}^{+}, \mathrm{NO}_{3}^{-}$ and OrgN. In Fig. 3, we can observe an enrichment of ${ }^{15} \mathrm{~N}$ in $\mathrm{TN}$ in summer when the lowest $\mathrm{NO}_{3}^{-}$contribution occurs. Thus, higher $\delta^{15} \mathrm{~N}$ values of TN in summer are mainly caused by higher abundances of $\mathrm{NH}_{4}^{+}$originating from $\left(\mathrm{NH}_{4}\right)_{2} \mathrm{SO}_{4}$, OrgN and ammonium salts of organic acids.

Furthermore, we observed one of the largest enrichments of ${ }^{15} \mathrm{~N}$ of $\mathrm{TN}$ in summer aerosols as compared to previous studies (Kundu et al., 2010, and references therein), which may be explained through several reasons. First, the previous studies mainly focused on total suspended particles (TSPs); however, we focused on the fine fraction $\left(\mathrm{PM}_{1}\right)$, whose surface should be more reactive due to a larger surface area per unit of aerosol mass than the coarse fraction and consequently result in a higher abundance of ${ }^{15} \mathrm{~N}$ during the gas and particle portioning between $\mathrm{NH}_{3}$ and $\mathrm{NH}_{4}^{+}$. Second, fine accumulation mode particles have a longer residence time in the atmosphere than the coarse mode fraction, which is also a factor that results in an enrichment of ${ }^{15} \mathrm{~N}$. Indeed, Mkoma et al. (2014) reported average higher $\delta^{15} \mathrm{~N}$ of $\mathrm{TN}$ in fine $\left(17.4 \%, \mathrm{PM}_{2.5}\right)$ over coarse aerosols $\left(12.1 \%\right.$ o, $\left.\mathrm{PM}_{10}\right)$. Freyer (1991) also reported higher $\delta^{15} \mathrm{~N}_{\text {of }} \mathrm{NO}_{3}^{-}(4.2 \%$ to $8 \%$ ) in fine aerosols $(<3.5 \mu \mathrm{m})$ in comparison with the coarse mode $(-1.4 \%$ to $5.5 \%$ o). Third, a shorter sampling interval of our work $(24 \mathrm{~h})$ leads to a higher chance of collecting episodic samples such as the winter event, which could not be clearly detected due to averaged (overlapped) aerosols over a longer sampling period (e.g., weekly samples).

Similarly, as in this study, the highest $\delta^{15} \mathrm{~N}$ values in TN were observed in a few studies from the Indian region (Aggarwal et al., 2013; Bikkina et al., 2016; Pavuluri et al., 2010), where biomass burning is the common source and ambient temperatures are high. Therefore, in addition to the above reasons, temperature also plays a significant role in ${ }^{15} \mathrm{~N}$ enrichment. This point will be discussed in more detail in Sect. 3.3.

Figure 4 shows the $\delta^{15} \mathrm{~N}$ of $\mathrm{TN}$ as a function of $\mathrm{NO}_{3}^{-}$ concentration. Samples with the highest $\mathrm{NO}_{3}^{-}$concentrations $\left(>6 \mu \mathrm{g} \mathrm{m}^{-3}, n=5\right.$ ) show an average $\delta^{15} \mathrm{~N}$ of $13.3 \pm 0.7 \%$ o. Assuming that $\mathrm{NO}_{3}^{-}$in the fine aerosol fraction consists predominantly of $\mathrm{NH}_{4} \mathrm{NO}_{3}$ (Harrison and Pio, 1983), it can be stated that ammonium nitrate is a source of nitrogen at the Košetice site, with $\delta^{15} \mathrm{~N}$ values at approximately $13.3 \%$, which is similar to the winter values of $\delta^{15} \mathrm{~N}_{\text {in }} \mathrm{NO}_{3}^{-}$in other studies. Specifically, Kundu et al. (2010) reported a winter average of $\delta^{15} \mathrm{~N}$ of $\mathrm{NO}_{3}^{-}$at $+15.9 \%$ from a Pacific marine site at Gosan, Jeju Island, South Korea, whereas Freyer (1991) reported $+9.2 \%$ at a moderately polluted site from Jülich, Germany. Yeatman et al. (2001b) reported approximately $+9 \%$ from a coastal site at Weybourne, UK. Park et al. (2018) reported 11.9\%o in Seoul and 11.7\%o from a rural site on Baengnyeong Island, South Korea.

Considering the $\delta^{15} \mathrm{~N}$ of nitrogen oxides, which are common precursors of particulate nitrate, we can see that the $\delta^{15} \mathrm{~N}$ of nitrogen oxides generated by coal combustion (Felix et al., 2012; $+6 \%$ to $+13 \%$, Heaton, 1990) or biomass burning $(+14 \%$, Felix et al., 2012) are in the same range as our $\delta^{15} \mathrm{~N}$ during the period of enhanced concentrations of $\mathrm{NO}_{3}^{-}$. These $\delta^{15} \mathrm{~N}$ values of nitrogen oxides are also significantly higher than those from vehicular exhaust $(-13 \%$ to $-2 \%$, Heaton, $1990 ;-19 \%$ o to $+9 \%$ o, Walters et al., 2015b) or biogenic soil ( $-48 \%$ o to $-19 \%$, Li and Wang, 2008). Because of the slight difference between above-reported $\delta^{15} \mathrm{~N}$ of nitrogen oxides and our $\delta^{15} \mathrm{~N}$ of TN during maximal $\mathrm{NO}_{3}^{-}$ events, the isotope composition is probably influenced by the process of kinetic isotopic fractionation in fossil fuel combustion samples during the heating season as referred to by Ciężka et al. (2016) as one of three possible processes. Thus, $\delta^{15} \mathrm{~N}$ values around $13.3 \%$ (Fig. 4) are probably characteristic of fresh emissions from heating (both coal and biomass burning) because these values are obtained during the domestic heating season.

The exponential curves in Fig. 4 represent a boundary in which $\delta^{15} \mathrm{~N}$ values are migrating as a result of the enrichment or depletion of ${ }^{15} \mathrm{~N}$, which is associated with the removal or loading of $\mathrm{NO}_{3}^{-}$in aerosols. These curves represent two opposed chemical processes converting at approximately $13.3 \%$, which shows a strong logarithmic correlation $(r=0.96$ during the winter event, represented by the green line, and -0.81 for the rest of points, represented by 


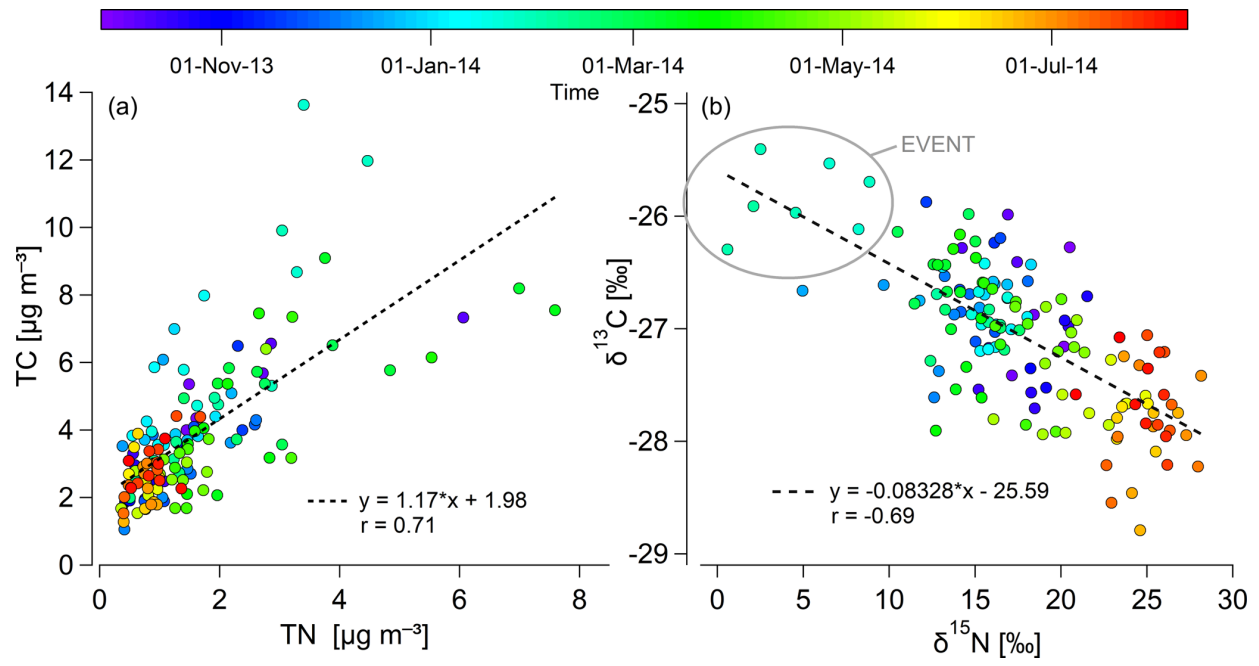

Figure 2. Relationships between TC and TN (a) and their stable carbon and nitrogen isotopes (b). The color scale reflects the time of sample collection. The gray circle highlights the winter event measurements.

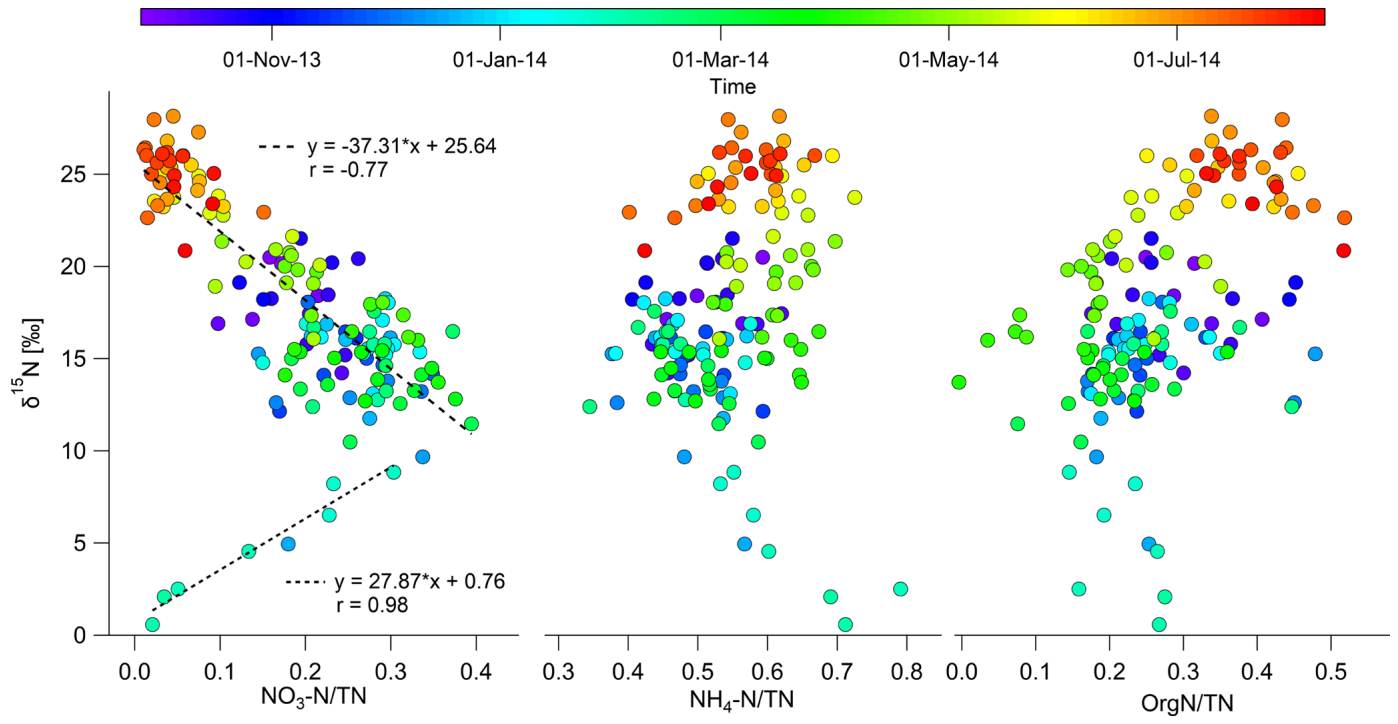

Figure 3. Changes in $\delta^{15} \mathrm{~N}$ depending on fraction of individual nitrogen components $\left(\mathrm{NO}_{3}-\mathrm{N}, \mathrm{NH}_{4}-\mathrm{N}\right.$ and OrgN) in $\mathrm{TN}$. The color scale reflects the time of sample collection.

the black line; see Fig. S3). These results indicate a significant and different mechanism through which nitrogen isotopic fractionation occurs in aerosols. In both cases, the decrease in nitrate leads to exponential changes in the enrichment or depletion of ${ }^{15} \mathrm{~N}$ from a value of $13.3 \%$. In the case of enrichment, in addition to a higher proportion of $\mathrm{NH}_{4}^{+}$ than $\mathrm{NO}_{3}^{-}$, the dissociation process of $\mathrm{NH}_{4} \mathrm{NO}_{3}$ can cause an increase in ${ }^{15} \mathrm{~N}$ of TN during a period of higher ambient temperatures, as hypothesized by Pavuluri et al. (2010).

Although it represents a significant fraction of TN, OrgN has not been widely studied compared to particulate $\mathrm{NO}_{3}^{-}$ and $\mathrm{NH}_{4}^{+}$(e.g., Jickells et al., 2013; Neff et al., 2002; Pavuluri et al., 2015a). Figure 5 shows the relationship between $\delta^{15} \mathrm{~N}$ of TN and OrgN. Organic nitrogen consists of organic compounds containing nitrogen in water-soluble and insoluble fractions. The majority of samples have a concentration range of 0.1-0.5 $\mu \mathrm{g} \mathrm{m}^{-3}$ (gray highlight in Fig. 5), which can be considered background OrgN at the Košetice site. During the domestic heating season with the highest concentrations of $\mathrm{NO}_{3}^{-}$and $\mathrm{NH}_{4}^{+}$, we can observe a significant increase in OrgN with $\delta^{15} \mathrm{~N}$ again at approximately $13.3 \%$, which implies that the isotopic composition of $\mathrm{OrgN}$ is determined by the same source. In the case of emissions from combustion, OrgN originates mainly from biomass burning (Jickells et al., 2013, and references therein), and thus elevated concentrations of $\mathrm{OrgN}$ (as well as high $\mathrm{NO}_{3}^{-}$and $\mathrm{NH}_{4}^{+}$conc.) may 


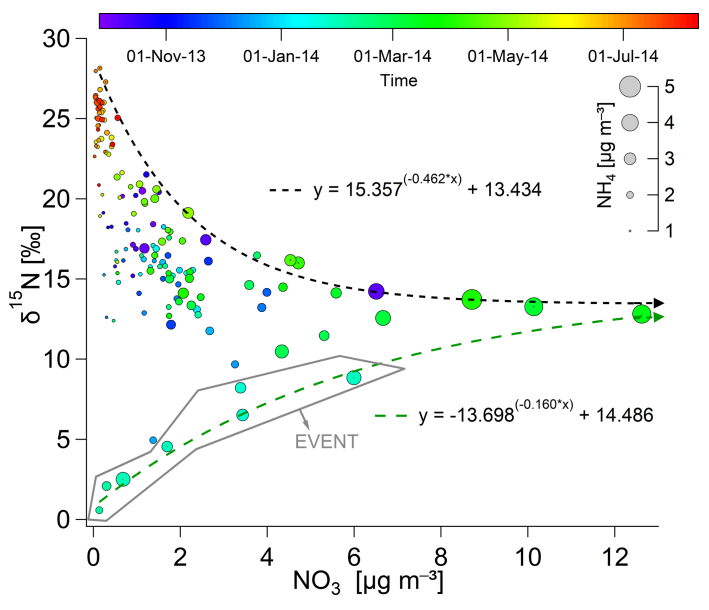

Figure 4. Relationships of $\delta^{15} \mathrm{~N}$ of $\mathrm{TN}$ vs. $\mathrm{NO}_{3}^{-}$concentrations. The larger circles indicate higher $\mathrm{NH}_{4}^{+}$concentrations. The color scale reflects the time of sample collection.

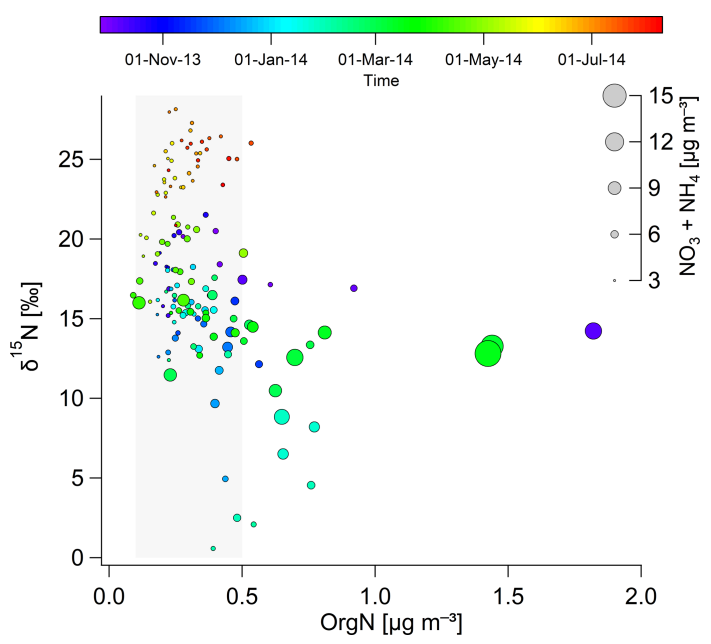

Figure 5. Relationships of $\delta^{15} \mathrm{~N}$ of $\mathrm{TN}$ vs. OrgN concentrations. The larger circles indicate higher sums of $\mathrm{NO}_{3}^{-}+\mathrm{NH}_{4}^{+}$concentrations. The color scale reflects the time of sample collection, and the highlighted portion is a concentration range between 0.1 and $0.5 \mu \mathrm{g} \mathrm{m}^{-3}$.

refer to this source. On the other hand, looking at the trend of OrgN/TN vs. $\delta^{15} \mathrm{~N}$ (Fig. 3) it is more similar to the trend of $\mathrm{NH}_{4}^{+}-\mathrm{N} / \mathrm{TN}$ than $\mathrm{NO}_{3}^{-}-\mathrm{N} / \mathrm{TN}$. Thus, it can be considered that the changes in the $\delta^{15} \mathrm{~N}$ of OrgN in samples that are highlighted as a gray area in Fig. 5 are probably driven more by the same changes in $\mathrm{NH}_{4}^{+}$particles, especially in summer with elevated OrgN in TN (Table 1).

\subsection{Total carbon and its $\delta^{13} \mathrm{C}$}

The $\delta^{13} \mathrm{C}$ of TC ranged from $-28.9 \%$ to $-25.4 \%$ (Fig. 6) and the lowest $\delta^{13} \mathrm{C}$ we observed was in blank field samples (mean $-29.2 \%, n=7$ ), indicating that the lowest summer

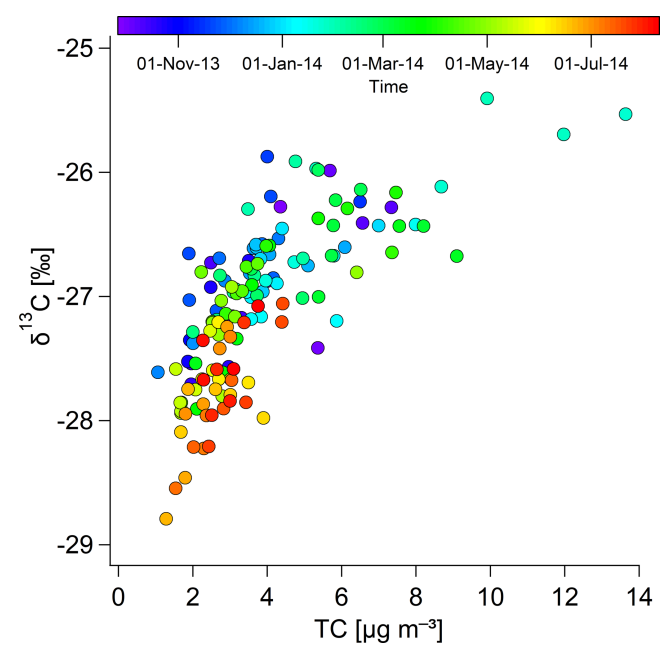

Figure 6. Relationship between TC and $\delta^{13} \mathrm{C}$. The color scale reflects the time of sample collection.

values in particulate matter were close to gas-phase values. Our $\delta^{13} \mathrm{C}$ values are within the range reported for particulate TC $(-29 \%$ o to $-15 \%$ o ) as summarized by Gensch et al. (2014). The lowest values are associated with fine particles after combustion and transport (Ancelet et al., 2011; Widory, 2006), while the highest values are associated with the coarse fraction and carbonate contribution (Kawamura et al., 2004). This broad range can be explained by the influence of marine aerosols (Ceburnis et al., 2016), different anthropogenic sources (e.g., Widory et al., 2004) as well as different distributions of $C_{3}$ and $C_{4}$ plants (Martinelli et al., 2002), resulting in different $\delta^{13} \mathrm{C}$ values in the Northern Hemisphere and Southern Hemisphere (Cachier, 1989). The $\delta^{13} \mathrm{C}$ values at the Košetice site fall within the range common to other European sites: for example, a rural background site in Vavihill (southern Sweden, range $-26.7 \%$ o to $-25.6 \%$, Martinsson et al., 2017), urban Wrocław (Poland, range $-27.6 \%$ o to $-25.3 \%$, Górka et al., 2014), different sites (urban, coastal, forest) in Lithuania (eastern Europe, Masalaite et al., 2015, 2017), as well as urban Zurich (Switzerland, Fisseha et al., 2009a).

The range of TC $\delta^{13} \mathrm{C}$ values is significantly narrower than that of TN $\delta^{15} \mathrm{~N}$ due to a higher number of carbonaceous components in the aerosol mixture whose isotope ratios overlap one another. However, it is possible to distinguish lower $\delta^{13} \mathrm{C}$ values in summer (Table 1), which may indicate a contribution from higher terrestrial plant emissions. Similarly, Martinsson et al. (2017) reported lower $\delta^{13} \mathrm{C}$ values in summer in comparison with other seasons, which they explain through high biogenic aerosol contributions from $\mathrm{C}_{3}$ plants.

A similar dependence of $\delta^{13} \mathrm{C}$ on the TC concentration was observed by Fisseha et al. (2009), where winter ${ }^{13} \mathrm{C}$ enrichment was associated with WSOC (water-soluble organic carbon) that originated mainly from wood combustion. Similarly, at the Košetice station different carbonaceous aerosols 
were observed during the heating season (October-April) to those in summer (Mbengue et al., 2018; Vodička et al., 2015). Moreover, winter aerosols at the Košetice site were probably affected by not only biomass burning but also coal burning (Schwarz et al., 2016), which can result in higher carbon contents and more ${ }^{13} \mathrm{C}$-enriched particles (Widory, 2006). Furthermore, based on the number of size distribution measurements at the Košetice site, larger particles were observed in winter in comparison with summer, even in the fine particle fraction (Zíková and Ždímal, 2013), which can also have an effect on lower $\delta^{13} \mathrm{C}$ values in summer. Thus, the relatively low $\delta^{13} \mathrm{C}$ values in our range (up to $-28.9 \%$ ) are because fine particles have lower $\delta^{13} \mathrm{C}$ values in comparison with coarse particles probably due to different sources of TC. (e.g., Masalaite et al., 2015; Skipitytè et al., 2016).

\subsection{Temperature dependence and correlations of $\delta^{15} \mathrm{~N}$ and $\delta^{13} \mathrm{C}$ with other variables}

Tables 2 and 3 show Spearman's correlation coefficients $(r)$ of $\delta^{15} \mathrm{~N}$ and $\delta^{13} \mathrm{C}$ with different variables that may reflect some effects on isotope distributions. In addition to yearround correlations, correlations for each season, as well as for the event, are presented separately.

Correlations of $\delta^{15} \mathrm{~N}$ in winter and summer are often the opposite of one another (e.g., for TN -0.40 in winter vs. 0.36 in summer, for $\mathrm{NH}_{4}^{+}-0.42$ in winter vs. 0.40 in summer), indicating that aerosol chemistry at the nitrogen level is different in these seasons. Similarly, the contradictory dependence between $\delta^{15} \mathrm{~N}$ and TN in summer and winter was observed by Widory (2007) in $\mathrm{PM}_{10}$ samples from Paris. Widory (2007) connected this result with different primary nitrogen origin (traffic emissions in summer and no specific source in winter) and following secondary processes associated with isotope fractionation during the degradation of atmospheric nitrogen oxides, leading to two distinct pathways for ${ }^{15} \mathrm{~N}$ enrichment (summer) and depletion (winter).

From a meteorological point of view, a significant correlation of $\delta^{15} \mathrm{~N}$ with temperature has been obtained, indicating the influence of temperature on nitrogen isotopic composition. The dependence of $\delta^{15} \mathrm{~N}$ of TN on temperature (Fig. 7) is similar to that observed by Ciężka et al. (2016) for $\delta^{15} \mathrm{~N}$ of $\mathrm{NH}_{4}^{+}$from precipitation; however, it is the opposite of that observed by Freyer (1991) for $\delta^{15} \mathrm{~N}$ of $\mathrm{NO}_{3}^{-}$. The aforementioned studies concluded that the isotope equilibrium exchange between nitrogen oxides and particulate nitrates is temperature dependent and could lead to more ${ }^{15} \mathrm{~N}$ enriched $\mathrm{NO}_{3}^{-}$during the cold season (Freyer et al., 1993; Savard et al., 2017). Although Savard et al. (2017) reported a similar negative temperature dependence for $\delta^{15} \mathrm{~N}$ of $\mathrm{NH}_{4}^{+}$ in Alberta (Canada), most studies reported a positive temperature dependence for $\delta^{15} \mathrm{~N}$ of $\mathrm{NH}_{4}^{+}$that is stronger than that for $\delta^{15} \mathrm{~N}$ of $\mathrm{NO}_{3}^{-}$(e.g., Kawashima and Kurahashi, 2011; Kundu et al., 2010). The reason is that $\mathrm{NH}_{3}$ gas concentrations are higher during warmer conditions, and thus the iso- topic equilibrium exchange reaction is more intensive, i.e., $\mathrm{NH}_{3}(\mathrm{~g}) \leftrightarrow \mathrm{NH}_{4}^{+}(\mathrm{p})$, which leads to ${ }^{15} \mathrm{~N}$ enrichment in particles.

All the considerations mentioned above indicate that a resulting relationship between $\delta^{15} \mathrm{~N}$ of TN and temperature is driven by the prevailing nitrogen species, which is $\mathrm{NH}_{4}^{+}$in our case. A similar dependence was reported by Pavuluri et al. (2010) between temperature and $\delta^{15} \mathrm{~N}$ of TN in Chennai (India), where $\mathrm{NH}_{4}^{+}$strongly prevailed. They found the best correlation between $\delta^{15} \mathrm{~N}$ and temperature during the colder period (range of $18.4-24.5^{\circ} \mathrm{C}$, average of $21.2^{\circ} \mathrm{C}$ ); however, during warmer periods, this dependence was weakened. In our study, we observed the highest correlation of $\delta^{15} \mathrm{~N}$ with temperature in autumn $(r=0.58$, temperature range of -1.9 to $13.9^{\circ} \mathrm{C}$, average of $6.6^{\circ} \mathrm{C}$ ), followed by spring $\left(r=0.52\right.$, temperature range of $1.5-18.7^{\circ} \mathrm{C}$, average of $9.3^{\circ} \mathrm{C}$ ), but there was even a negative but insignificant correlation in summer (temperature range of $11.8-25.5^{\circ} \mathrm{C}$, average of $17.7^{\circ} \mathrm{C}$ ). This result indicates that ambient temperature plays an important role in the enrichment and depletion of ${ }^{15} \mathrm{~N}$; however, it is not determined by a specific temperature range but rather the conditions for repeating the process of "evaporation and condensation", as shown by the comparison with the work of Pavuluri et al. (2010). It is likely that isotopic fractionation caused by the equilibrium reaction of $\mathrm{NH}_{3}(\mathrm{~g}) \leftrightarrow \mathrm{NH}_{4}^{+}(\mathrm{p})$ reaches a certain level of enrichment under higher-temperature conditions in summer.

In summer, $\delta^{15} \mathrm{~N}$ correlates positively with $\mathrm{NH}_{4}^{+}(r=$ $0.40)$ and $\mathrm{SO}_{4}^{2-}(0.51)$, indicating a link with $\left(\mathrm{NH}_{4}\right)_{2} \mathrm{SO}_{4}$ that is enriched by ${ }^{15} \mathrm{~N}$ due to aging. Figure 8 shows an enrichment of ${ }^{15} \mathrm{~N}$ as a function of the molar ratio of $\mathrm{NH}_{4}^{+} / \mathrm{SO}_{4}^{2-}$. The highest $\mathrm{NH}_{4}^{+} / \mathrm{SO}_{4}^{2-}$ ratios, showing an ammonia-rich atmosphere, were observed during winter, late autumn and early spring along with high abundance of $\mathrm{NO}_{3}^{-}$ that is related to favorable thermodynamic conditions during the heating season and enough ammonia in the atmosphere. Gradually decreasing molar ratios of $\mathrm{NH}_{4}^{+} / \mathrm{SO}_{4}^{2-}$ during spring indicate a gradual increase in ambient temperatures and therefore worsened thermodynamic conditions for $\mathrm{NO}_{3}^{-}$formation in the aerosol phase, which was accompanied by a visible decrease in the nitrate content in aerosols (Fig. 8). The increase in temperature finally leads to the $\mathrm{NH}_{4}^{+} / \mathrm{SO}_{4}^{2-}$ ratio reaching 2 as spring turns to summer. Finally, summer values of $\mathrm{NH}_{4}^{+} / \mathrm{SO}_{4}^{2-}$ molar ratio below 2 indicate that $\mathrm{SO}_{4}^{2-}$ in aerosol particles at high summer temperatures may not be completely saturated with ammonium but it can be composed from a mixture of $\left(\mathrm{NH}_{4}\right)_{2} \mathrm{SO}_{4}$ and $\mathrm{NH}_{4} \mathrm{HSO}_{4}$ (Weber et al., 2016). The equilibrium reaction between these two forms of ammonium sulfates is related to temperature oscillation during the day and, due to vertical mixing of the atmosphere, is a probable factor that leads to increased values of $\delta^{15} \mathrm{~N}$ in early summer. Ammonia measurements, carried out at the Košetice site until 2001, showed that $\mathrm{NH}_{3}$ concentrations in summer were slightly higher 
Table 2. Spearman correlation coefficients $(r)$ of $\delta^{15} \mathrm{~N}$ with various tracers. Only bold values are statistically significant $(p$ values $<0.05)$.

\begin{tabular}{lrrrrrr}
\hline$\delta^{15} \mathrm{~N}$ vs. & Autumn & Winter* & Spring & Summer & Year* & Event \\
\hline $\mathrm{TN}$ & -0.30 & $-\mathbf{0 . 4 0}$ & $-\mathbf{0 . 7 0}$ & $\mathbf{0 . 3 6}$ & $\mathbf{- 0 . 5 4}$ & $\mathbf{0 . 9 3}$ \\
$\mathrm{TN} / \mathrm{PM}_{1}$ & $-\mathbf{0 . 6 3}$ & $-\mathbf{0 . 5 0}$ & -0.02 & $\mathbf{0 . 3 7}$ & $-\mathbf{0 . 3 5}$ & 0.36 \\
$\mathrm{NO}_{3}^{-}-\mathrm{N} / \mathrm{TN}$ & -0.39 & -0.04 & $-\mathbf{0 . 7 3}$ & -0.26 & $-\mathbf{0 . 7 7}$ & $\mathbf{0 . 9 8}$ \\
$\mathrm{NH}_{4}^{+}-\mathrm{N} / \mathrm{TN}$ & 0.16 & -0.30 & $\mathbf{0 . 6 0}$ & $\mathbf{0 . 5 2}$ & $\mathbf{0 . 4 2}$ & $\mathbf{- 0 . 8 6}$ \\
$\mathrm{OrgN} / \mathrm{TN}$ & 0.20 & $\mathbf{0 . 3 8}$ & 0.20 & -0.33 & $\mathbf{0 . 5 1}$ & -0.71 \\
$\mathrm{NO}_{3}^{-}$ & $-\mathbf{0 . 4 1}$ & $-\mathbf{0 . 3 5}$ & $-\mathbf{0 . 8 0}$ & -0.03 & $-\mathbf{0 . 7 8}$ & $\mathbf{0 . 9 6}$ \\
$\mathrm{NH}_{4}^{+}$ & -0.22 & $-\mathbf{0 . 4 2}$ & $-\mathbf{0 . 6 1}$ & $\mathbf{0 . 4 0}$ & $-\mathbf{0 . 4 4}$ & 0.75 \\
$\mathrm{OrgN}^{+}$ & -0.26 & -0.27 & $-\mathbf{0 . 5 6}$ & 0.30 & $-\mathbf{0 . 2 5}$ & 0.71 \\
$\mathrm{SO}_{4}^{2-}$ & -0.07 & $-\mathbf{0 . 3 8}$ & -0.30 & $\mathbf{0 . 5 1}$ & 0.03 & -0.57 \\
$\mathrm{Cl}^{-}$ & -0.37 & -0.18 & $-\mathbf{0 . 7 4}$ & $-\mathbf{0 . 3 7}$ & $-\mathbf{0 . 7 4}$ & $\mathbf{0 . 9 9}$ \\
$\mathrm{O}_{3}$ (gas) & $\mathbf{0 . 4 5}$ & 0.14 & 0.15 & -0.02 & $\mathbf{0 . 4 0}$ & -0.71 \\
$\mathrm{NO}_{2}$ (gas) & $\mathbf{- 0 . 5 3}$ & $-\mathbf{0 . 3 4}$ & $-\mathbf{0 . 7 2}$ & 0.20 & $-\mathbf{0 . 6 4}$ & $\mathbf{0 . 8 6}$ \\
$\mathrm{NO}_{2} / \mathrm{NO}$ (gas) & $\mathbf{- 0 . 5 1}$ & -0.26 & $-\mathbf{0 . 8 2}$ & 0.14 & $-\mathbf{0 . 7 6}$ & $\mathbf{0 . 8 2}$ \\
$\mathrm{Temp}$ & $\mathbf{0 . 5 8}$ & 0.30 & $\mathbf{0 . 5 2}$ & -0.21 & $\mathbf{0 . 7 7}$ & -0.43 \\
\hline
\end{tabular}

* Event data are excluded from winter and year-long datasets.

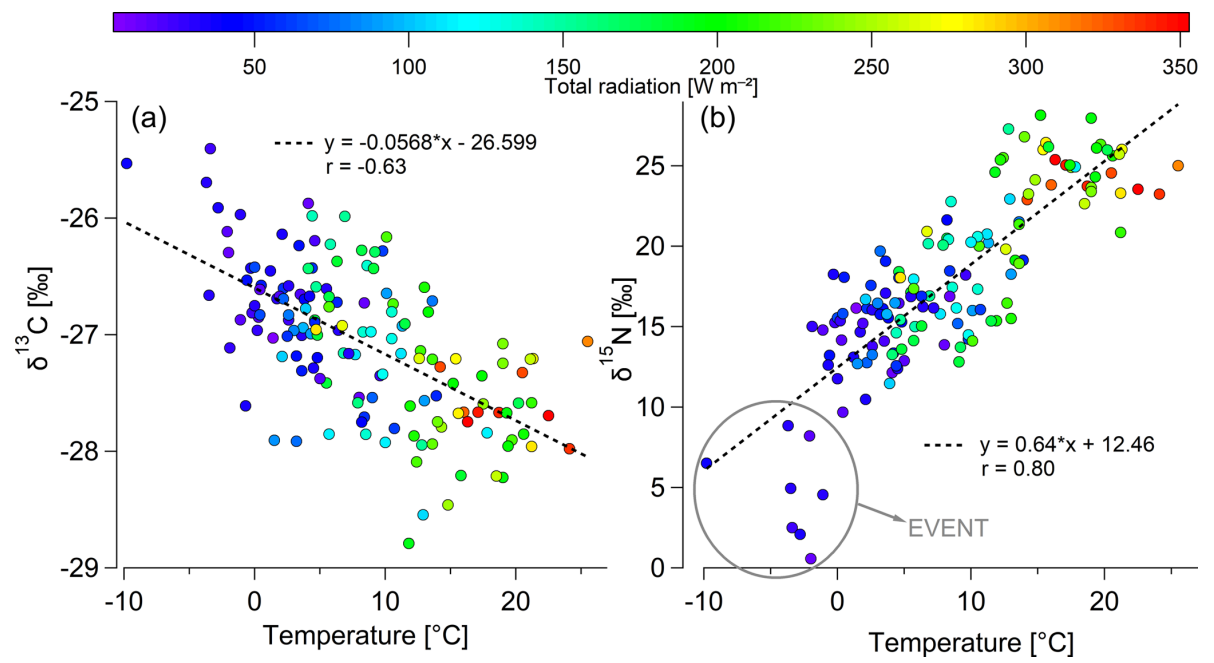

Figure 7. Relationships between temperature and $\delta^{13} \mathrm{C}$ of TC (a) and $\delta^{15} \mathrm{~N}$ of TN (b). The color scale reflects the total radiation.

than in winter (http://portal.chmi.cz/files/portal/docs/uoco/ isko/tab_roc/2000_enh/CZE/kap_18/kap_18_026.html, last access: 15 March 2019), which supports temperature as a main factor influencing the $\mathrm{NH}_{4}^{+} / \mathrm{SO}_{4}^{2-}$ ratio at Košetice. In this context, we noticed that 25 out of 33 summer samples have molar ratios of $\mathrm{NH}_{4}^{+} / \mathrm{SO}_{4}^{2-}$ below 2 , the remaining samples are approximately 2 and the relative abundance of $\mathrm{NO}_{3}^{-}$in $\mathrm{PM}_{1}$ in those samples is very low (ca. 1.7\%).

Recently, Silvern et al. (2017) reported that organic aerosols can play a role in modifying or retarding the achievement of $\mathrm{H}_{2} \mathrm{SO}_{4}-\mathrm{NH}_{3}$ thermodynamic equilibrium at $\mathrm{NH}_{4}^{+} / \mathrm{SO}_{4}^{2-}$ molar ratios of less than 2 , even when sufficient amounts of ammonia are present in the gas phase. Thus, an interaction between sulfates and ammonia may be hindered due to the preferential reaction with aged aerosols coated with organics (Liggio et al., 2011). In thermodynamic equilibrium, partitioning between gas $\left(\mathrm{NH}_{3}\right)$ and aerosol $\left(\mathrm{NH}_{4}^{+}\right)$ phases should result in even larger $\delta^{15} \mathrm{~N}$ values of particles in summer; however, measurements show a different situation. Summer $\delta^{15} \mathrm{~N}$ values are highest but further enrichment was stopped. Moreover, we observed a positive (and significant) correlation between temperature and $\delta^{13} \mathrm{C}(r=0.39)$ only in summer, whereas the correlation coefficient of $\delta^{15} \mathrm{~N}$ vs. temperature is statistically insignificant, suggesting that while values of $\delta^{15} \mathrm{~N}$ reached their maxima, the $\delta^{13} \mathrm{C}$ can still grow with even higher temperatures due to the influence of organics in the summer season.

As seen in Table 3, summertime positive correlations of $\delta^{13} \mathrm{C}$ with ozone $(r=0.66)$ and temperature $(0.39)$ indicate oxidation processes that can indirectly lead to an enrichment 
Table 3. Spearman correlation coefficients $(r)$ of $\delta^{13} \mathrm{C}$ with various tracers. Only bold values are statistically significant $(p$ values $<0.05)$.

\begin{tabular}{lrrrrrr}
\hline$\delta^{13} \mathrm{C}$ vs. & Autumn & Winter* & Spring & Summer & Year* & Event \\
\hline $\mathrm{OC}$ & $\mathbf{0 . 6 4}$ & $\mathbf{0 . 6 3}$ & $\mathbf{0 . 9 1}$ & $\mathbf{0 . 3 9}$ & $\mathbf{0 . 7 5}$ & 0.75 \\
$\mathrm{EC}$ & $\mathbf{0 . 6 1}$ & $\mathbf{0 . 7 4}$ & $\mathbf{0 . 8 8}$ & 0.28 & $\mathbf{0 . 8 4}$ & 0.46 \\
$\mathrm{EC} / \mathrm{TC}$ & 0.06 & 0.06 & 0.13 & $-\mathbf{0 . 5 1}$ & $\mathbf{0 . 3 2}$ & -0.32 \\
$\mathrm{TC} / \mathrm{PM}_{1}$ & -0.16 & -0.05 & $-\mathbf{0 . 4 0}$ & 0.22 & -0.09 & 0.32 \\
$\mathrm{NO}_{3}^{-}$ & $\mathbf{0 . 7 4}$ & $\mathbf{0 . 5 2}$ & $\mathbf{0 . 7 1}$ & 0.12 & $\mathbf{0 . 7 6}$ & 0.39 \\
$\mathrm{NH}_{4}^{+}$ & $\mathbf{0 . 8 4}$ & $\mathbf{0 . 5 9}$ & $\mathbf{0 . 8 0}$ & $\mathbf{0 . 4 2}$ & $\mathbf{0 . 6 6}$ & 0.75 \\
$\mathrm{Oxalate}^{2-}$ & 0.34 & $\mathbf{0 . 6 2}$ & $\mathbf{0 . 7 1}$ & $\mathbf{0 . 6 5}$ & $\mathbf{0 . 2 5}$ & $\mathbf{0 . 9 3}$ \\
$\mathrm{SO}_{4}^{2-}$ & $\mathbf{0 . 8 0}$ & $\mathbf{0 . 6 4}$ & $\mathbf{0 . 7 3}$ & $\mathbf{0 . 4 1}$ & $\mathbf{0 . 3 4}$ & 0.54 \\
$\mathrm{~K}^{+}$ & $\mathbf{0 . 8 4}$ & $\mathbf{0 . 6 3}$ & $\mathbf{0 . 7 0}$ & $\mathbf{0 . 4 7}$ & $\mathbf{0 . 7 6}$ & $\mathbf{0 . 9 3}$ \\
$\mathrm{Cl}^{-}$ & $\mathbf{0 . 4 4}$ & $\mathbf{0 . 6 2}$ & $\mathbf{0 . 6 8}$ & $\mathbf{0 . 4 4}$ & $\mathbf{0 . 7 6}$ & 0.25 \\
$\mathrm{CO}^{-}$(gas) & 0.21 & $\mathbf{0 . 5 3}$ & $\mathbf{0 . 6 0}$ & 0.32 & $\mathbf{0 . 3 7}$ & 0.68 \\
$\mathrm{O}_{3}$ (gas) & $\mathbf{- 0 . 4 1}$ & -0.26 & 0.14 & $\mathbf{0 . 6 6}$ & $\mathbf{- 0 . 3 3}$ & 0.11 \\
$\mathrm{NO}_{2}$ (gas) & $\mathbf{0 . 6 7}$ & $\mathbf{0 . 3 8}$ & $\mathbf{0 . 7 0}$ & 0.18 & $\mathbf{0 . 6 9}$ & 0.32 \\
$\mathrm{NO}_{2} / \mathrm{NO}$ (gas) & $\mathbf{0 . 7 2}$ & $\mathbf{0 . 6 5}$ & $\mathbf{0 . 6 7}$ & $\mathbf{0 . 6 8}$ & $\mathbf{0 . 7 8}$ & $\mathbf{0 . 9 6}$ \\
$\mathrm{Temp}^{-}$ & -0.33 & $-\mathbf{0 . 3 5}$ & -0.20 & $\mathbf{0 . 3 9}$ & $-\mathbf{0 . 5 7}$ & $-\mathbf{0 . 7 9}$ \\
\hline
\end{tabular}

* Event data are excluded from winter and year-long datasets.

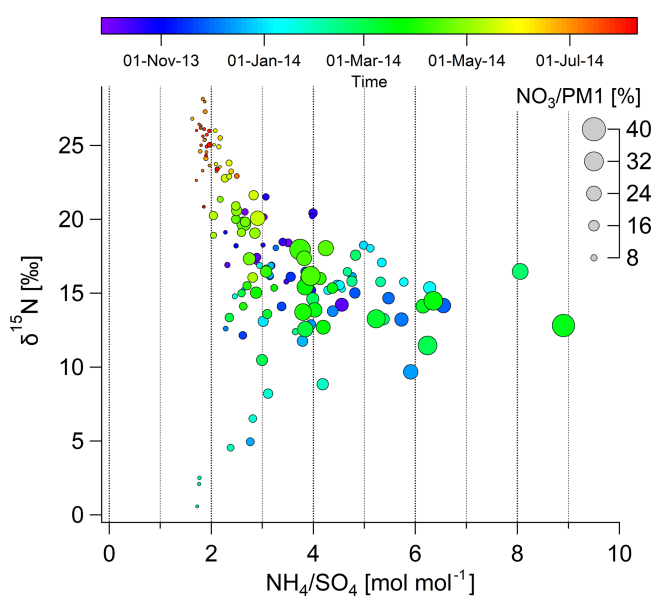

Figure 8. Relationships between $\delta^{15} \mathrm{~N}$ of $\mathrm{TN}$ and molar ratios of $\mathrm{NH}_{4}^{+} / \mathrm{SO}_{4}^{2-}$ in particles. The larger circle indicates higher nitrate content in $\mathrm{PM}_{1}$. The color scale reflects the time of sample collection.

of ${ }^{13} \mathrm{C}$ in organic aerosols that are enriched with oxalic acid (Pavuluri and Kawamura, 2016). This result is also supported by the fact that the content of oxalate in $\mathrm{PM}_{1}$, measured by IC, was twice as high in spring and summer than in winter and autumn. The influence of temperature on $\delta^{13} \mathrm{C}$ in winter is opposite to that in summer. The negative correlation $(-0.35)$ in winter probably indicates more fresh emissions from domestic heating (probably coal burning) with higher $\delta^{13} \mathrm{C}$ values during the cold season.

The whole-year temperature dependence of $\delta^{13} \mathrm{C}$ is the opposite of that observed for $\delta^{15} \mathrm{~N}$ (Fig. 7a), suggesting more ${ }^{13} \mathrm{C}$-depleted products in summer. This result is probably connected with different carbonaceous aerosols during win- ter (anthropogenic emissions from coal, wood and biomass burning with the enrichment of ${ }^{13} \mathrm{C}$ ) in comparison with the summer season (primary biogenic and secondary organic aerosols with lower $\delta^{13} \mathrm{C}$ ) (Vodička et al., 2015). The data of $\delta^{13} \mathrm{C}$ in Fig. 7 are also more scattered, which indicates that in the case of carbon, the isotopic composition depends more on sources than on temperature.

Correlations of $\delta^{13} \mathrm{C}$ with $\mathrm{OC}$ are significant in all seasons; they are strongest in spring and weakest in summer (Table 3). Correlations of $\delta^{13} \mathrm{C}$ with $\mathrm{EC}$, whose main sources are combustion processes from domestic heating and transportation, are significant ( $r=0.61-0.88)$ only during the heating season (autumn-spring; see Table 3), while in summer the correlation is statistically insignificant $(0.28)$. Thus, the isotopic composition of aerosol carbon at the Košetice station is not significantly influenced by EC emitted from transportation; otherwise the year-round correlation between $\delta^{13} \mathrm{C}$ and $\mathrm{EC}$ would suggest that transportation is significant source of EC in summer. This result can be biased by the fact that EC constitutes on average $19 \%$ of TC during all seasons. However, it is consistent with positive correlations between $\delta^{13} \mathrm{C}$ and gaseous $\mathrm{NO}_{2}$, as well as particulate nitrate, which is also significant from autumn to spring. This result is also supported by the negative correlation of $\delta^{13} \mathrm{C}$ with the EC/TC ratio $(r=-0.51)$, which is only significant in summer.

It should be mentioned that the wind directions during the campaign were similar, with the exception of the winter season, when southeast (SE) winds prevailed (see Fig. S4). We did not observe any specific dependence of isotopic values on wind directions except for during the event. 


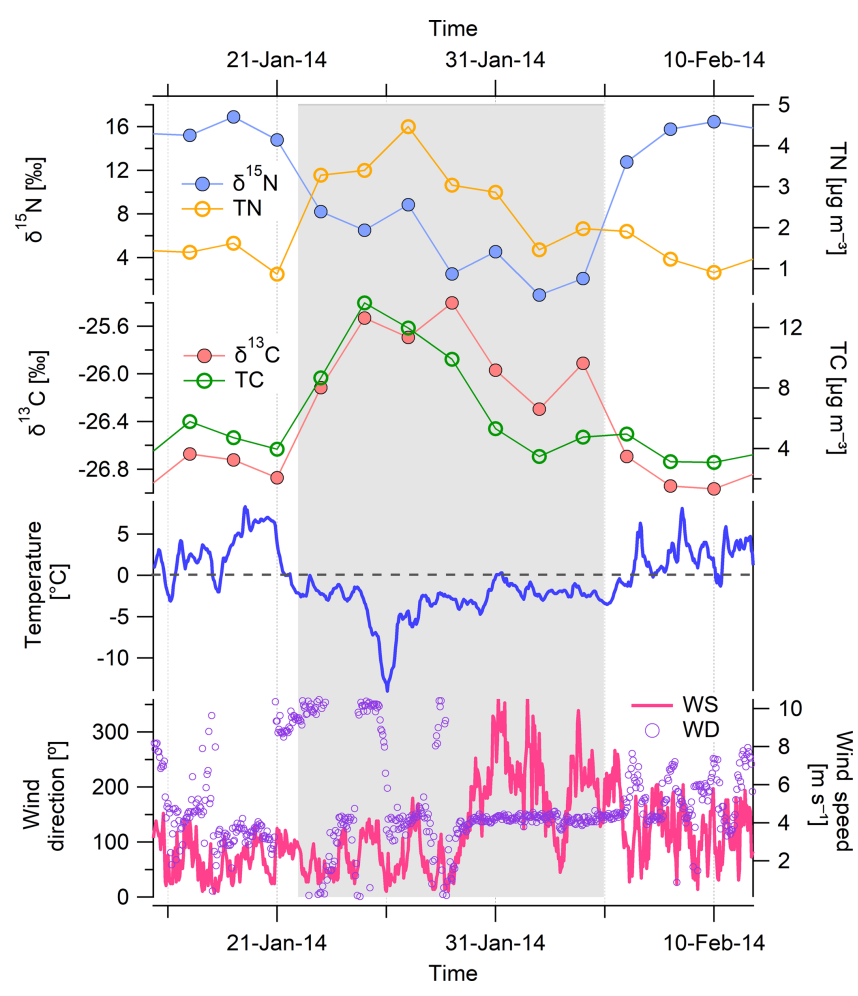

Figure 9. Time series of $\delta^{15} \mathrm{~N}, \mathrm{TN}, \delta^{13} \mathrm{C}$, TC and meteorological variables (temperature, wind speed and direction, and $1 \mathrm{~h}$ time resolution) during the event, which is highlighted by the gray color.

\subsection{The winter event}

The winter event represents the period from 23 January to 5 February 2014, when an enrichment of ${ }^{13} \mathrm{C}$ and substantial depletion of ${ }^{15} \mathrm{~N}$ occurred in $\mathrm{PM}_{1}$ (see Figs. 1 and 9 for details). We do not observe any trends of the isotopic compositions of $\delta^{15} \mathrm{~N}$ and $\delta^{13} \mathrm{C}$ with wind directions except for the period of the event and one single measurement on $18 \mathrm{De}$ cember 2013. Both the event and the single measurement are connected to SE winds through Vienna and the Balkan Peninsula (Fig. 10). More elevated wind speeds with very stable SE winds are observed on the site with samples showing the most ${ }^{15} \mathrm{~N}$-depleted values at the end of the event (Fig. 9). Stable weather conditions and the homogeneity of the results indicate a local or regional source, which is probably associated with the formation of sulfates (Fig. S5).

Although the event only contains seven samples, high correlations are obtained for $\delta^{15} \mathrm{~N}$ and $\delta^{13} \mathrm{C}$ (Tables 2 and 3). Generally, correlations of $\delta^{15} \mathrm{~N}$ with several parameters during the event are the opposite of those of four seasons, indicating the exceptional nature of these aerosols from a chemical point of view. During the event, $\delta^{15} \mathrm{~N}$ correlates positively with $\mathrm{NO}_{3}^{-}(r=0.96)$ and $\mathrm{NO}_{3}^{-}-\mathrm{N} / \mathrm{TN}(0.98)$. Before the event, we also observed the highest values of $\delta^{15} \mathrm{~N}$ at approximately $13.3 \%$, which we previously interpreted as an influence of the emissions from domestic heating via coal and/or biomass burning. Positive correlations of $\delta^{13} \mathrm{C}$ with oxalate and potassium (both 0.93 ) and the negative correlation with temperature $(-0.79)$ also suggest that the event is associated with fresh emissions from burning sources.

In contrast, we find that most $\delta^{15} \mathrm{~N}$ values with a depletion of ${ }^{15} \mathrm{~N}$ are associated with enhanced $\mathrm{NH}_{4}^{+}$contents (70\%-80\% of TN) and almost absence of $\mathrm{NO}_{3}^{-}$nitrogen (see Figs. 3 and 4). Although some content of OrgN is detected during the event (Fig. 3), the correlation between $\delta^{15} \mathrm{~N}$ and OrgN/TN is not significant (Table 2). This result suggests that nitrogen with the lowest $\delta^{15} \mathrm{~N}$ values is mainly connected with $\mathrm{NH}_{4}^{+}$, which is supported by a strong negative correlation between $\delta^{15} \mathrm{~N}$ and $\mathrm{NH}_{4}^{+} / \mathrm{TN}(-0.86)$. Assuming that nitrogen in particles mainly originates from gaseous nitrogen precursors via gas-to-particle conversion (e.g., Wang et al., 2017) during the event, we could expect the nitrogen originated mainly from $\mathrm{NH}_{3}$ with depleted ${ }^{15} \mathrm{~N}$ but not nitrogen oxides. Agricultural emissions from both fertilizer application and animal waste are important sources of $\mathrm{NH}_{3}$ (Felix et al., 2013). In terms of possible agriculture emission sources, there are several collective farms with both livestock (mainly cows, Holstein cattle) and crop production in the SE direction from the Košetice observatory: namely, Agropodnik Košetice (3.4 km away), Agrodam Hořepník $(6.8 \mathrm{~km})$ and Agrosev Červená Řečice $(9.5 \mathrm{~km})$. Skipitytẻ et al. (2016) reported lower $\delta^{15} \mathrm{~N}$ values of TN $(+1 \%$ o to $+6 \%$ o) for agriculturederived particulate matter of poultry farms, which are close to our values obtained during the event (Fig. 9).

The $\delta^{15} \mathrm{~N}$ values from the event are associated with an average temperature of below $0{ }^{\circ} \mathrm{C}$ (Figs. 7 and 9). Savard et al. (2017) observed the lowest values of $\delta^{15} \mathrm{~N}_{\text {of }} \mathrm{NH}_{3}$ with temperatures below $-5^{\circ} \mathrm{C}$, and the $\mathrm{NH}_{4}^{+}$particles that were simultaneously sampled were also isotopically lighter compared to the samples collected under higher-temperature conditions. They interpreted the result as a preferential dry deposition of heavier isotopic ${ }^{15} \mathrm{NH}_{3}$ species during the cold period, whereas lighter ${ }^{14} \mathrm{NH}_{3}$ species preferentially remain in the atmosphere. However, cold weather can also lead to a decline of ammonia fluxes from aerosol water surfaces, soil, etc. (Roelle and Aneja, 2002), which generally result in a deficit of ammonia in the atmosphere. Emissions from farms are not as limited by low temperature and are thus a main source of ammonia in this deficiency state. The removal of $\mathrm{NH}_{3}$ leads to a nonequilibrium state between the gas and aerosol phases. Such an absence of equilibrium exchange of $\mathrm{NH}_{3}$ between the gas and liquid and solid phases is considered to cause the $\mathrm{NH}_{4}^{+} / \mathrm{SO}_{4}^{2-}$ molar ratios below 2 for the three most ${ }^{15} \mathrm{~N}$-depleted samples (Fig. 8). However, under such conditions, nitrate partitioning in PM is negligible. It should be mentioned that a deficiency of ammonia in the atmosphere during the winter event leads to completely opposite $\delta^{15} \mathrm{~N}$ values than in summer (see Sect. 3.3) even if molar ratios $\mathrm{NH}_{4}^{+} / \mathrm{SO}_{4}^{2-}$ are below 2 in both cases.

Unidirectional reactions of isotopically lighter $\mathrm{NH}_{3}$ with $\mathrm{H}_{2} \mathrm{SO}_{4}$ in the atmosphere are strongly preferred by the ki- 
NOAA HYSPLIT MODEL Backward trajectories ending at 06:00 UTC 05 Feb 2014 GDAS meteorological data

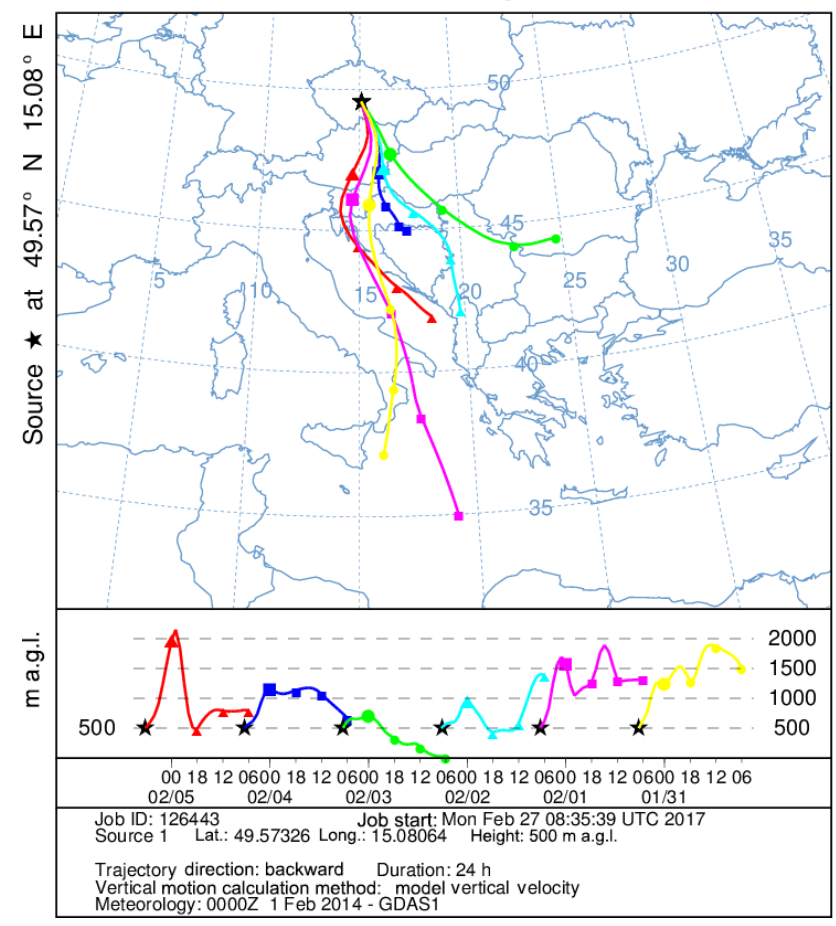

Figure 10. NOAA HYSPLIT (Stein et al., 2015) $24 \mathrm{~h}$ backward air mass trajectories at $500 \mathrm{~m}$ a.g.l. for the observation site from 30 January until 5 February 2014.

netic isotope effect, which is, after several minutes, followed by enrichment of ${ }^{14} \mathrm{NH}_{3}$ due to the newly established equilibrium (Heaton et al., 1997). Based on laboratory experiments, Heaton et al. (1997) estimated the isotopic enrichment factor

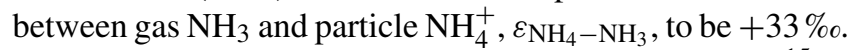
Savard et al. (2017) reported an isotopic difference $\left(\Delta \delta^{15} \mathrm{~N}\right)$ between $\mathrm{NH}_{3}(\mathrm{~g})$ and particulate $\mathrm{NH}_{4}^{+}$as a function of temperature, whereas $\Delta \delta^{15} \mathrm{~N}$ for a temperature of approximately $0{ }^{\circ} \mathrm{C}$ was approximately $40 \%$. In both cases, after subtraction of these values $\left(33 \%\right.$ or $40 \%$ ) from the $\delta^{15} \mathrm{~N}$ values of the measured event, we obtain values from approximately $-40 \%$ o to $-28 \%$, which are in a range of $\delta^{15} \mathrm{~N}-\mathrm{NH}_{3}(\mathrm{~g})$ measured for agricultural emissions. These values are in especially good agreement with $\delta^{15} \mathrm{~N}$ of $\mathrm{NH}_{3}$ derived from cow waste (ca. $-38 \%$ o to $-22 \%$, Felix et al., 2013).

Thus, during the course of the winter event, we probably observed PM representing a mixture of aerosols from household heating characterized by higher amounts of $\mathrm{NO}_{3}^{-}$ and the low value $\left(8.2 \%\right.$ ) of $\delta^{15} \mathrm{~N}$ of $\mathrm{TN}$, which are gradually replaced by ${ }^{15} \mathrm{~N}$-depleted agricultural aerosols. The whole process occurred under low-temperature conditions that were first initiated by a deficiency of $\mathrm{NH}_{3}$ followed by a unidirectional (kinetic) reaction of isotopically lighter $\mathrm{NH}_{3}(\mathrm{~g}) \rightarrow \mathrm{NH}_{4}^{+}(\mathrm{p})$, in which $\mathrm{NH}_{3}$ is mainly originated from agricultural sources SE of the Košetice station.
If the four lowest values of $\delta^{15} \mathrm{~N}$ mainly represent agricultural aerosols, then it can be suggested that the $\delta^{13} \mathrm{C}$ values from the same samples should originate from the same sources. During the winter event, the $\delta^{13} \mathrm{C}$ values ranging from $-26.2 \%$ to $-25.4 \%$ o belong to the most ${ }^{13} \mathrm{C}$-enriched fine aerosols at the Košetice site. However, similar $\delta^{13} \mathrm{C}$ values were reported by Widory (2006) for particles from coal combustion ( $-25.6 \%$ to $-24.6 \%$ ). Skipityte et al. (2016) reported a mean value of $\delta^{13} \mathrm{C}$ of TC $(-23.7 \pm 1.3 \%$ ) for $\mathrm{PM}_{1}$ particles collected on a poultry farm and suggested litter as a possible source for the particles. Thus, in the case of $\delta^{13} \mathrm{C}$, values that we observed during the winter event are more probably caused by emissions from domestic heating than from agricultural sources. This is also supported by increased emissions of $\mathrm{SO}_{2}$ from coal combustion to formation of sulfates.

\section{Summary and conclusions}

Based on the analysis of year-round data of stable carbon and nitrogen isotopes, we extracted important information on the processes taking place in fine aerosols during different seasons at the Central European station of Košetice. Seasonal variations were observed for $\delta^{13} \mathrm{C}$ and $\delta^{15} \mathrm{~N}$, as well as for $\mathrm{TC}$ and TN concentrations. The supporting data (i.e., ions, EC and OC, meteorology, and trace gases) revealed characteristic processes that led to changes in the isotopic compositions on the site.

The main and gradual changes in nitrogen isotopic composition occurred in spring. During early spring, domestic heating with wood stoves is still common, with high nitrate concentrations in aerosols, which decreased toward the end of spring. Additionally, the temperature slowly increases and the overall situation leads to thermodynamic equilibrium exchange between gas $\left(\mathrm{NO}_{x}-\mathrm{NH}_{3}-\mathrm{SO}_{2}\right.$ mixture) and aerosol $\left(\mathrm{NO}_{3}^{-}-\mathrm{NH}_{4}^{+}-\mathrm{SO}_{4}^{2-}\right.$ mixture) phases, which causes an enrichment of ${ }^{15} \mathrm{~N}$ in aerosols. Enrichment of ${ }^{15} \mathrm{~N}\left(\Delta \delta^{15} \mathrm{~N}\right)$ from the beginning to the end of spring was approximately $+10 \%$. Gradual springtime changes in isotopic composition were also observed for $\delta^{13} \mathrm{C}$, but the depletion was small and $\Delta \delta^{13} \mathrm{C}$ was only $-1.4 \%$.

In summer, we observed the lowest concentrations of TC and $\mathrm{TN}$; however, there was an enhanced enrichment of ${ }^{15} \mathrm{~N}$, which was probably caused by the aging of nitrogenous aerosols, where ammonium sulfate and bisulfate are subjected to isotopic fractionation via equilibrium exchange between $\mathrm{NH}_{3}(\mathrm{~g})$ and $\mathrm{NH}_{4}^{+}(\mathrm{p})$ when the $\mathrm{NH}_{4}^{+} / \mathrm{SO}_{4}^{2-}$ molar ratio was less than 2. However, summer values of $\delta^{15} \mathrm{~N}$ were still among the highest compared with those in previous studies, which can be explained by several factors. First, a fine aerosol fraction $\left(\mathrm{PM}_{1}\right)$ is more reactive and its residence time in the atmosphere is longer than coarse mode particles, leading to ${ }^{15} \mathrm{~N}$ enrichment in aged aerosols. Second, summer aerosols, compared to other seasons, contain a negligi- 
ble amount of nitrate, contributing to a decrease in the average value of $\delta^{15} \mathrm{~N}$ of TN. Although the summer $\delta^{15} \mathrm{~N}$ values were the highest, further ${ }^{15} \mathrm{~N}$ enrichment was minimized at this season. On the other hand, we observed an enrichment of ${ }^{13} \mathrm{C}$ only in summer, which can be explained by the photooxidation processes of organics and is supported by the positive correlation of $\delta^{13} \mathrm{C}$ with temperature and ozone. Despite this slow enrichment process, summertime $\delta^{13} \mathrm{C}$ values were the lowest compared to those in other seasons and referred predominantly to organic aerosols of biogenic origin.

In winter, we found the highest concentrations of TC and TN. Lower winter $\delta^{15} \mathrm{~N}$ values were apparently influenced by fresh aerosols from combustion, which were strongly driven by the amount of nitrates (mainly $\mathrm{NH}_{4} \mathrm{NO}_{3}$ in $\mathrm{PM}_{1}$ ) and led to an average winter value $\left(13.3 \pm 0.7 \%\right.$ of $\delta^{15} \mathrm{~N}$ of $\mathrm{TN}$. Winter $\delta^{13} \mathrm{C}$ values were more enriched than summer values, which are involved with the emissions from biomass and coal burning for domestic heating.

We observed an aerosol event in winter, which was characterized by low temperatures below the freezing point, stable southeast winds and a unique isotope signature with a depletion of ${ }^{15} \mathrm{~N}$ and enrichment of ${ }^{13} \mathrm{C}$. The winter event characterized by ${ }^{15} \mathrm{~N}$ depletion was probably caused by preferential unidirectional reactions between isotopically light ammonia, which mainly originated from agriculture emissions, and sulfuric acid, resulting in $\left(\mathrm{NH}_{4}\right)_{2} \mathrm{SO}_{4}$ and $\mathrm{NH}_{4} \mathrm{HSO}_{4}$. This process was probably supported by long-term cold weather, leading to a deficiency of ammonia in the atmosphere (due to dry deposition and/or low fluxes) and subsequent suppression of nitrate to partitioning in aerosol.

The majority of yearly data showed a strong correlation between $\delta^{15} \mathrm{~N}$ and ambient temperature, demonstrating an enrichment of ${ }^{15} \mathrm{~N}$ via isotopic equilibrium exchange between the gas and particulate phases. This process seemed to be one of the main mechanisms for ${ }^{15} \mathrm{~N}$ enrichment at the Košetice site, especially during spring. The most ${ }^{15} \mathrm{~N}$ enriched summer and most ${ }^{15} \mathrm{~N}$-depleted winter samples were limited for the partitioning of nitrate between gas and aerosols.

This study revealed a picture of the seasonal cycle of $\delta^{15} \mathrm{~N}$ in aerosol TN at the Košetice site. The seasonal $\delta^{13} \mathrm{C}$ cycle was not so pronounced because they mainly depend on the isotopic composition of primary sources, which often overlapped. Although photochemical secondary oxidation reactions are driven by the kinetic isotopic effect, the phase transfer probably did not play a crucial role in the case of carbon at the Central European site.

Data availability. All relevant data for this paper are archived at the ICPF (Institute of Chemical Process Fundamentals) and are available upon request from the corresponding author (Petr Vodička).
Supplement. The supplement related to this article is available online at: https://doi.org/10.5194/acp-19-3463-2019-supplement.

Author contributions. All authors contributed to the final version of this article. PV analyzed isotopes, total carbon and nitrogen, and EC and OC and evaluated data and wrote the paper under the supervision of KK. JS was responsible for gravimetric results, as well as ion, EC, and OC measurements, and contributed to the revision of the text. BK prepared samples for isotope analyses. VZ managed the field campaign and provided advice and feedback throughout the drafting and submission process.

Competing interests. The authors declare that they have no conflict of interest.

Acknowledgements. This study was supported by funding from the Japan Society for the Promotion of Science (JSPS) through grant-in-aid no. 24221001, from the Ministry of Education, Youth and Sports of the Czech Republic under project no. LM2015037, and under the grant ACTRIS-CZ RI (CZ.02.1.01/0.0/0.0/16_013/0001315). We also thank the Czech Hydrometeorological Institute for providing its meteorological data and Milan Váňa and his colleagues from the Košetice Observatory for their valuable cooperation during the collection of samples. We appreciate the financial support of the JSPS fellowship to Petr Vodička (P16760).

Review statement. This paper was edited by Nikolaos Mihalopoulos and reviewed by two anonymous referees.

\section{References}

Aggarwal, S. G., Kawamura, K., Umarji, G. S., Tachibana, E., Patil, R. S., and Gupta, P. K.: Organic and inorganic markers and stable $\mathrm{C}$-, $\mathrm{N}$-isotopic compositions of tropical coastal aerosols from megacity Mumbai: sources of organic aerosols and atmospheric processing, Atmos. Chem. Phys., 13, 4667-4680, https://doi.org/10.5194/acp-13-4667-2013, 2013.

Agnihotri, R., Mandal, T. K., Karapurkar, S. G., Naja, M., Gadi, R., Ahammmed, Y. N., Kumar, A., Saud, T., and Saxena, M.: Stable carbon and nitrogen isotopic composition of bulk aerosols over India and northern Indian Ocean, Atmos. Environ., 45, 28282835, https://doi.org/10.1016/j.atmosenv.2011.03.003, 2011.

Ancelet, T., Davy, P. K., Trompetter, W. J., Markwitz, A., and Weatherburn, D. C.: Carbonaceous aerosols in an urban tunnel, Atmos. Environ., 45, 4463-4469, https://doi.org/10.1016/j.atmosenv.2011.05.032, 2011.

Beyn, F., Matthias, V., Aulinger, A., and Dähnke, K.: Do $\mathrm{N}$-isotopes in atmospheric nitrate deposition reflect air pollution levels?, Atmos. Environ., 107, 281-288, https://doi.org/10.1016/j.atmosenv.2015.02.057, 2015.

Bikkina, S., Kawamura, K., and Sarin, M.: Stable carbon and nitrogen isotopic composition of fine mode aerosols $\left(\mathrm{PM}_{2.5}\right)$ over 
the Bay of Bengal: impact of continental sources, Tellus B, 68, 31518, https://doi.org/10.3402/tellusb.v68.31518, 2016.

Boreddy, S. K. R., Parvin, F., Kawamura, K., Zhu, C., and Lee, C. Te: Stable carbon and nitrogen isotopic compositions of fine aerosols $\left(\mathrm{PM}_{2.5}\right)$ during an intensive biomass burning over Southeast Asia: Influence of SOA and aging, Atmos. Environ., 191, 478-489, https://doi.org/10.1016/j.atmosenv.2018.08.034, 2018.

Cachier, H.: Isotopic characterization of carbonaceous aerosols, Aerosol Sci. Technol., 10, 379-385, https://doi.org/10.1080/02786828908959276, 1989.

Cavalli, F., Viana, M., Yttri, K. E., Genberg, J., and Putaud, J.-P.: Toward a standardised thermal-optical protocol for measuring atmospheric organic and elemental carbon: the EUSAAR protocol, Atmos. Meas. Tech., 3, 79-89, https://doi.org/10.5194/amt-3-792010, 2010.

Ceburnis, D., Masalaite, A., Ovadnevaite, J., Garbaras, A., Remeikis, V., Maenhaut, W., Claeys, M., Sciare, J., Baisnée, D., and O'Dowd, C. D.: Stable isotopes measurements reveal dual carbon pools contributing to organic matter enrichment in marine aerosol, Sci. Rep., 6, 1-6, https://doi.org/10.1038/srep36675, 2016.

Ciężka, M., Modelska, M., Górka, M., Trojanowska-Olichwer, A., and Widory, D.: Chemical and isotopic interpretation of major ion compositions from precipitation: A one-year temporal monitoring study in Wrocław, SW Poland, J. Atmos. Chem., 73, 6180, https://doi.org/10.1007/s10874-015-9316-2, 2016.

Dean, J. R., Leng, M. J., and Mackay, A. W.: Is there an isotopic signature of the Anthropocene?, Anthr. Rev., 1, 276-287, https://doi.org/10.1177/2053019614541631, 2014.

Felix, D. J., Elliott, E. M., Gish, T. J., McConnell, L. L., and Shaw, S. L.: Characterizing the isotopic composition of atmospheric ammonia emission sources using passive samplers and a combined oxidation-bacterial denitrifier approach, Rapid Commun. Mass Spectrom., 27, 2239-2246, https://doi.org/10.1002/rcm.6679, 2013.

Felix, J. D., Elliott, E. M., and Shaw, S. L.: Nitrogen isotopic composition of coal-fired power plant NOx: Influence of emission controls and implications for global emission inventories, Environ. Sci. Technol., 46, 3528-3535, https://doi.org/10.1021/es203355v, 2012.

Fisseha, R., Saurer, M., Jäggi, M., Siegwolf, R. T. W., Dommen, J., Szidat, S., Samburova, V., and Baltensperger, U.: Determination of primary and secondary sources of organic acids and carbonaceous aerosols using stable carbon isotopes, Atmos. Environ., 43, 431-437, https://doi.org/10.1016/j.atmosenv.2008.08.041, 2009a.

Fisseha, R., Spahn, H., Wegener, R., Hohaus, T., Brasse, G., Wissel, H., Tillmann, R., Wahner, A., Koppmann, R., and KiendlerScharr, A.: Stable carbon isotope composition of secondary organic aerosol from $\beta$-pinene oxidation, J. Geophys. Res., 114, D02304, https://doi.org/10.1029/2008JD011326, 2009b.

Freyer, H. D.: Seasonal variation of ${ }^{15} \mathrm{~N} /{ }^{14} \mathrm{~N}$ ratios in atmospheric nitrate species, Tellus B, 43, 30-44, https://doi.org/10.1034/j.1600-0889.1991.00003.x, 1991.

Freyer, H. D., Kley, D., Volz-Thomas, A., and Kobel, K.: On the interaction of isotopic exchange processes with photochemical reactions in atmospheric oxides of nitrogen, J. Geophys. Res., 98, 14791-14796, https://doi.org/10.1029/93JD00874, 1993.
Fuzzi, S., Baltensperger, U., Carslaw, K., Decesari, S., Denier van der Gon, H., Facchini, M. C., Fowler, D., Koren, I., Langford, B., Lohmann, U., Nemitz, E., Pandis, S., Riipinen, I., Rudich, Y., Schaap, M., Slowik, J. G., Spracklen, D. V., Vignati, E., Wild, M., Williams, M., and Gilardoni, S.: Particulate matter, air quality and climate: lessons learned and future needs, Atmos. Chem. Phys., 15, 8217-8299, https://doi.org/10.5194/acp15-8217-2015, 2015.

Gensch, I., Kiendler-Scharr, A., and Rudolph, J.: Isotope ratio studies of atmospheric organic compounds: Principles, methods, applications and potential, Int. J. Mass Spectrom., 365-366, 206221, https://doi.org/10.1016/j.ijms.2014.02.004, 2014.

Górka, M., Rybicki, M., Simoneit, B. R. T., and Marynowski, L.: Determination of multiple organic matter sources in aerosol $\mathrm{PM}_{10}$ from Wrocław, Poland using molecular and stable carbon isotope compositions, Atmos. Environ., 89, 739-748, https://doi.org/10.1016/j.atmosenv.2014.02.064, 2014.

Harrison, R. M. and Pio, C. A.: Size-differentiated composition of inorganic atmospheric aerosols of both marine and polluted continental origin, Atmos. Environ., 17, 1733-1738, https://doi.org/10.1016/0004-6981(83)90180-4, 1983.

Heaton, T. H. E.: ${ }^{15} \mathrm{~N} /{ }^{14} \mathrm{~N}$ ratios of $\mathrm{NO}_{x}$ from vehicle engines and coal-fired power stations, Tellus B, 42, 304-307, 1990.

Heaton, T. H. E., Spiro, B., and Robertson, S. M. C.: Potential canopy influences on the isotopic composition of nitrogen and sulphur in atmospheric deposition, Oecologia, 109, 600-607, 1997.

Hyslop, N. P.: Impaired visibility: the air pollution people see, Atmos. Environ., 43, 182-195, https://doi.org/10.1016/j.atmosenv.2008.09.067, 2009.

Irei, S., Huang, L., Collin, F., Zhang, W., Hastie, D., and Rudolph, J.: Flow reactor studies of the stable carbon isotope composition of secondary particulate organic matter generated by OH-radicalinduced reactions of toluene, Atmos. Environ., 40, 5858-5867, https://doi.org/10.1016/j.atmosenv.2006.05.001, 2006.

Jickells, T., Baker, A. R., Cape, J. N., Cornell, S. E., and Nemitz, E.: The cycling of organic nitrogen through the atmosphere, Philos. T. Roy. Soc. B, 368, 20130115, https://doi.org/10.1098/rstb.2013.0115, 2013.

Kawamura, K., Kobayashi, M., Tsubonuma, N., Mochida, M., Watanabe, T., and Lee, M.: Organic and inorganic compositions of marine aerosols from East Asia: Seasonal variations of watersoluble dicarboxylic acids, major ions, total carbon and nitrogen, and stable $\mathrm{C}$ and $\mathrm{N}$ isotopic composition, Geo. Soc. S. P., 9, 243 265, https://doi.org/10.1016/S1873-9881(04)80019-1, 2004.

Kawashima, H. and Haneishi, Y.: Effects of combustion emissions from the Eurasian continent in winter on seasonal $\delta^{13} \mathrm{C}$ of elemental carbon in aerosols in Japan, Atmos. Environ., 46, 568579, https://doi.org/10.1016/j.atmosenv.2011.05.015, 2012.

Kawashima, H. and Kurahashi, T.: Inorganic ion and nitrogen isotopic compositions of atmospheric aerosols at Yurihonjo, Japan: Implications for nitrogen sources, Atmos. Environ., 45, 63096316, https://doi.org/10.1016/j.atmosenv.2011.08.057, 2011.

Kundu, S., Kawamura, K., and Lee, M.: Seasonal variation of the concentrations of nitrogenous species and their nitrogen isotopic ratios in aerosols at Gosan, Jeju Island: Implications for atmospheric processing and source changes of aerosols, J. Geophys. Res.-Atmos., 115, 1-19, https://doi.org/10.1029/2009JD013323, 2010. 
Kunwar, B., Kawamura, K., and Zhu, C.: Stable carbon and nitrogen isotopic compositions of ambient aerosols collected from Okinawa Island in the western North Pacific Rim, an outflow region of Asian dusts and pollutants, Atmos. Environ., 131, 243-253, https://doi.org/10.1016/j.atmosenv.2016.01.035, 2016.

Li, D. and Wang, X.: Nitrogen isotopic signature of soil-released nitric oxide (NO) after fertilizer application, Atmos. Environ., 42, 4747-4754, https://doi.org/10.1016/j.atmosenv.2008.01.042, 2008.

Liggio, J., Li, S. M., Vlasenko, A., Stroud, C., and Makar, P.: Depression of ammonia uptake to sulfuric acid aerosols by competing uptake of ambient organic gases, Environ. Sci. Technol., 45, 2790-2796, https://doi.org/10.1021/es103801g, 2011.

Martinelli, L. A., Camargo, P. B., Lara, L. B. L. S., Victoria, R. L., and Artaxo, P.: Stable carbon and nitrogen isotopic composition of bulk aerosol particles in a $\mathrm{C}_{4}$ plant landscape of southeast Brazil, Atmos. Environ., 36, 2427-2432, https://doi.org/10.1016/S1352-2310(01)00454-X, 2002.

Martinsson, J., Andersson, A., Sporre, M. K., Friberg, J., Kristensson, A., Swietlicki, E., Olsson, P. A., and Stenström, K. E.: Evaluation of $\delta^{13} \mathrm{C}$ in carbonaceous aerosol source apportionment at a rural measurement site, Aerosol Air Qual. Res., 17, 2081-2094, https://doi.org/10.4209/aaqr.2016.09.0392, 2017.

Masalaite, A., Remeikis, V., Garbaras, A., Dudoitis, V., Ulevicius, V., and Ceburnis, D.: Elucidating carbonaceous aerosol sources by the stable carbon $\delta^{13} \mathrm{C}_{\mathrm{TC}}$ ratio in size-segregated particles, Atmos. Res., 158-159, 1-12, https://doi.org/10.1016/j.atmosres.2015.01.014, 2015.

Masalaite, A., Holzinger, R., Remeikis, V., Röckmann, T., and Dusek, U.: Characteristics, sources and evolution of fine aerosol $\left(\mathrm{PM}_{1}\right)$ at urban, coastal and forest background sites in Lithuania, Atmos. Environ., 148, 62-76, https://doi.org/10.1016/j.atmosenv.2016.10.038, 2017.

Mbengue, S., Fusek, M., Schwarz, J., Vodička, P., Šmejkalová, A. H., and Holoubek, I.: Four years of highly time resolved measurements of elemental and organic carbon at a rural background site in Central Europe, Atmos. Environ., 182, 335-346, https://doi.org/10.1016/j.atmosenv.2018.03.056, 2018.

Meier-Augenstein, W. and Kemp, H. F.: Stable Isotope Analysis: General Principles and Limitations, in Wiley Encyclopedia of Forensic Science, American Cancer Society, 2012.

Miyazaki, Y., Kawamura, K., Jung, J., Furutani, H., and Uematsu, M.: Latitudinal distributions of organic nitrogen and organic carbon in marine aerosols over the western North Pacific, Atmos. Chem. Phys., 11, 3037-3049, https://doi.org/10.5194/acp11-3037-2011, 2011.

Mkoma, S., Kawamura, K., Tachibana, E., and Fu, P.: Stable carbon and nitrogen isotopic compositions of tropical atmospheric aerosols: sources and contribution from burning of $\mathrm{C}_{3}$ and $\mathrm{C}_{4}$ plants to organic aerosols, Tellus B, 66, 20176, https://doi.org/10.3402/tellusb.v66.20176, 2014.

Morera-Gómez, Y., Santamaría, J. M., Elustondo, D., AlonsoHernández, C. M., and Widory, D.: Carbon and nitrogen isotopes unravels sources of aerosol contamination at Caribbean rural and urban coastal sites, Sci. Total Environ., 642, 723-732, https://doi.org/10.1016/j.scitotenv.2018.06.106, 2018.

Neff, J. C., Holland, E. A., Dentener, F. J., McDowell, W. H., and Russell, K. M.: The origin, composition and rates of organic ni- trogen deposition: a missing piece of the nitrogen cycle?, Biogeochemistry, 57/58, 99-136, 2002.

Park, Y., Park, K., Kim, H., Yu, S., Noh, S., Kim, M., Kim, J., Ahn, J., Lee, M., Seok, K., and Kim, Y.: Characterizing isotopic compositions of TC-C, $\mathrm{NO}^{-}-\mathrm{N}$, and $\mathrm{NH}_{4}^{+}-\mathrm{N}$ in $\mathrm{PM}_{2.5}$ in South Korea: Impact of China's winter heating, Environ. Pollut., 233, 735744, https://doi.org/10.1016/j.envpol.2017.10.072, 2018.

Pavuluri, C. M. and Kawamura, K.: Enrichment of ${ }^{13} \mathrm{C}$ in diacids and related compounds during photochemical processing of aqueous aerosols: New proxy for organic aerosols aging, Sci. Rep., 6, 36467, https://doi.org/10.1038/srep36467, 2016.

Pavuluri, C. M. and Kawamura, K.: Seasonal changes in TC and $\mathrm{WSOC}$ and their ${ }^{13} \mathrm{C}$ isotope ratios in Northeast Asian aerosols: land surface-biosphere-atmosphere interactions, Acta Geochim., 36, 355-358, https://doi.org/10.1007/s11631-0170157-3, 2017.

Pavuluri, C. M., Kawamura, K., Tachibana, E., and Swaminathan, T.: Elevated nitrogen isotope ratios of tropical Indian aerosols from Chennai: Implication for the origins of aerosol nitrogen in South and Southeast Asia, Atmos. Environ., 44, 3597-3604, https://doi.org/10.1016/j.atmosenv.2010.05.039, 2010.

Pavuluri, C. M., Kawamura, K., and Fu, P. Q.: Atmospheric chemistry of nitrogenous aerosols in northeastern Asia: biological sources and secondary formation, Atmos. Chem. Phys., 15, 9883-9896, https://doi.org/10.5194/acp-15-9883-2015, 2015a.

Pavuluri, C. M., Kawamura, K., and Swaminathan, T.: Timeresolved distributions of bulk parameters, diacids, ketoacids and $\alpha$-dicarbonyls and stable carbon and nitrogen isotope ratios of TC and TN in tropical Indian aerosols: Influence of land/sea breeze and secondary processes, Atmos. Res., 153, 188-199, https://doi.org/10.1016/j.atmosres.2014.08.011, 2015 b.

Pichlmayer, F., Schöner, W., Seibert, P., Stichler, W., and Wagenbach, D.: Stable isotope analysis for characterization of pollutants at high elevation alpine sites, Atmos. Environ., 32, 40754085, https://doi.org/10.1016/S1352-2310(97)00405-6, 1998.

Pokorná, P., Schwarz, J., Krejci, R., Swietlicki, E., Havránek, V., and Ždímal, V.: Comparison of $\mathrm{PM}_{2.5}$ chemical composition and sources at a rural background site in Central Europe between 1993/1994/1995 and 2009/2010: Effect of legislative regulations and economic transformation on the air quality, Environ. Pollut., 241, 841-851, https://doi.org/10.1016/j.envpol.2018.06.015, 2018.

Rahn, T. and Eiler, J. M.: Experimental constraints on the fractionation of ${ }^{13} \mathrm{C} /{ }^{12} \mathrm{C}$ and ${ }^{18} \mathrm{O} /{ }^{16} \mathrm{O}$ ratios due to adsorption of $\mathrm{CO}_{2}$ on mineral substrates at conditions relevant to the surface of Mars, Geochim. Cosmochim. Ac., 65, 839-846, 2001.

Roelle, P. A. and Aneja, V. P.: Characterization of ammonia emissions from soils in the upper coastal plain, North Carolina, Atmos. Environ., 36, 1087-1097, https://doi.org/10.1016/S13522310(01)00355-7, 2002.

Savard, M. M., Cole, A., Smirnoff, A., and Vet, R.: $\delta^{15} \mathrm{~N}$ values of atmospheric $\mathrm{N}$ species simultaneously collected using sector-based samplers distant from sources - Isotopic inheritance and fractionation, Atmos. Environ., 162, 11-22, https://doi.org/10.1016/j.atmosenv.2017.05.010, 2017.

Schwarz, J., Cusack, M., Karban, J., Chalupníčková, E., Havránek, V., Smolík, J., and Ždímal, V.: $\mathrm{PM}_{2.5}$ chemical composition at a rural background site in Central Europe, including correlation 
and air mass back trajectory analysis, Atmos. Res., 176-177, 108-120, https://doi.org/10.1016/j.atmosres.2016.02.017, 2016.

Silvern, R. F., Jacob, D. J., Kim, P. S., Marais, E. A., Turner, J. R., Campuzano-Jost, P., and Jimenez, J. L.: Inconsistency of ammonium-sulfate aerosol ratios with thermodynamic models in the eastern US: a possible role of organic aerosol, Atmos. Chem. Phys., 17, 5107-5118, https://doi.org/10.5194/acp17-5107-2017, 2017.

Skipitytè, R., Mašalaitè, A., Garbaras, A., Mickienè, R., Ragažinskienė, O., Baliukonienè, V., Bakutis, B., Šiugždaitè, J., Petkevičius, S., Maruška, A. S., and Remeikis, V.: Stable isotope ratio method for the characterisation of the poultry house environment, Isotopes Environ. Health Stud., 53, 243-260, https://doi.org/10.1080/10256016.2016.1230609, 2016.

Stein, A. F., Draxler, R. R., Rolph, G. D., Stunder, B. J. B., Cohen, M. D., and Ngan, F.: Noaa's hysplit atmospheric transport and dispersion modeling system, B. Am. Meteorol. Soc., 96, 20592077, https://doi.org/10.1175/BAMS-D-14-00110.1, 2015.

Stelson, A. W., Friedlander, S. K., and Seinfeld, J. H.: A note on the equilibrium relationship between ammonia and nitric acid and particulate ammonium nitrate, Atmos. Environ., 13, 369-371, https://doi.org/10.1016/0004-6981(79)90293-2, 1979.

Ti, C., Gao, B., Luo, Y., Wang, X., Wang, S., and Yan, X.: Isotopic characterization of $\mathrm{NHx}-\mathrm{N}$ in deposition and major emission sources, Biogeochemistry, 138, 85-102, https://doi.org/10.1007/s10533-018-0432-3, 2018.

Váňa, M. and Dvorská, A.: Košetice Observatory - 25 years, 1. edition, Czech Hydrometeorological Institute, Prague, 2014.

Vodička, P., Schwarz, J., Cusack, M., and Ždímal, V.: Detailed comparison of OC/EC aerosol at an urban and a rural Czech background site during summer and winter, Sci. Total Environ., 518519, 424-433, https://doi.org/10.1016/j.scitotenv.2015.03.029, 2015.

Walters, W. W., Simonini, D. S., and Michalski, G.: Nitrogen isotope exchange between $\mathrm{NO}$ and $\mathrm{NO}_{2}$ and its implications for $\delta^{15} \mathrm{~N}$ variations in tropospheric $\mathrm{NO}_{x}$ and atmospheric nitrate, Geophys. Res. Lett., 2, 1-26, https://doi.org/10.1002/2015GL066438, 2015a.

Walters, W. W., Goodwin, S. R., and Michalski, G.: Nitrogen stable isotope composition $\left(\delta^{15} \mathrm{~N}\right)$ of vehicleemitted $\mathrm{NO}_{x}$, Environ. Sci. Technol., 49, 2278-2285, https://doi.org/10.1021/es505580v, 2015b.

Wang, G., Xie, M., Hu, S., Gao, S., Tachibana, E., and Kawamura, K.: Dicarboxylic acids, metals and isotopic compositions of $\mathrm{C}$ and $\mathrm{N}$ in atmospheric aerosols from inland China: implications for dust and coal burning emission and secondary aerosol formation, Atmos. Chem. Phys., 10, 6087-6096, https://doi.org/10.5194/acp-10-6087-2010, 2010.

Wang, Y. L., Liu, X. Y., Song, W., Yang, W., Han, B., Dou, X. Y., Zhao, X. D., Song, Z. L., Liu, C. Q., and Bai, Z. P.: Source appointment of nitrogen in $\mathrm{PM}_{2.5}$ based on bulk $\delta^{15} \mathrm{~N}$ signatures and a Bayesian isotope mixing model, Tellus B, 69, 1-10, https://doi.org/10.1080/16000889.2017.1299672, 2017.
Weber, R. J., Guo, H., Russell, A. G., and Nenes, A.: High aerosol acidity despite declining atmospheric sulfate concentrations over the past 15 years, Nat. Geosci., 9, 282-285, https://doi.org/10.1038/ngeo2665, 2016.

Widory, D.: Combustibles, fuels and their combustion products: A view through carbon isotopes, Combust. Theor. Model., 10, 831841, https://doi.org/10.1080/13647830600720264, 2006.

Widory, D.: Nitrogen isotopes: Tracers of origin and processes affecting $\mathrm{PM}_{10}$ in the atmosphere of Paris, Atmos. Environ., 41, 2382-2390, https://doi.org/10.1016/j.atmosenv.2006.11.009, 2007.

Widory, D., Roy, S., Le Moullec, Y., Goupil, G., Cocherie, A., and Guerrot, C.: The origin of atmospheric particles in Paris: A view through carbon and lead isotopes, Atmos. Environ., 38, 953-961, https://doi.org/10.1016/j.atmosenv.2003.11.001, 2004.

Xiao, H.-W., Xiao, H.-Y., Luo, L., Zhang, Z.-Y., Huang, Q.-W., Sun, Q.-B., and Zeng, Z.: Stable carbon and nitrogen isotope compositions of bulk aerosol samples over the South China Sea, Atmos. Environ., 193, 1-10, https://doi.org/10.1016/j.atmosenv.2018.09.006, 2018.

Xue, D., Botte, J., Baets, B. De, Accoe, F., Nestler, A., Taylor, P., Cleemput, O. Van, Berglund, M., and Boeckx, P.: Present limitations and future prospects of stable isotope methods for nitrate source identification in surface- and groundwater, Water Res., 43 , 1159-1170, https://doi.org/10.1016/j.watres.2008.12.048, 2009.

Yeatman, S. G., Spokes, L. J., Dennis, P. F., and Jickells, T. D.: Can the study of nitrogen isotopic composition in size-segregated aerosol nitrate and ammonium be used to investigate atmospheric processing mechanisms?, Atmos. Environ., 35, 13371345, https://doi.org/10.1016/S1352-2310(00)00457-X, 2001a.

Yeatman, S. G., Spokes, L. J., Dennis, P. F., and Jickells, T. D.: Comparisons of aerosol nitrogen isotopic composition at two polluted coastal sites, Atmos. Environ., 35, 1307-1320, https://doi.org/10.1016/S1352-2310(00)00408-8, 2001b.

Zhang, Y. L., Kawamura, K., Cao, F., and Lee, M.: Stable carbon isotopic compositions of low-molecular-weight dicarboxylic acids, oxocarboxylic acids, $\alpha$-dicarbonyls, and fatty acids: Implications for atmospheric processing of organic aerosols, J. Geophys. Res.-Atmos., 121, 3707-3717, https://doi.org/10.1002/2015JD024081, 2016.

Zíková, N. and Ždímal, V.: Long-term measurement of aerosol number size distributions at rural background station Košetice, Aerosol Air Qual. Res., 13, 1464-1474, https://doi.org/10.4209/aaqr.2013.02.0056, 2013. 